\title{
XIX. YÜZYILIN ORTALARINDA ÇERKEŞ KAZASININ EKONOMIK DURUMU
}

\section{ECONOMIC SITUATION OF ÇERKES TOWN IN THE MIDDLE OF XIX. CENTURY}

\section{Ahmet YURTSEVEN*}

\section{Özet}

XIX. yüzyıl Osmanlı Devleti’nin siyasi, sosyal ve ekonomik alanlarda önemli değişiklikler yapmaya çalıştığı bir dönemdir. Söz konusu dönemde ekonomik alanda yapılan yeniliklerden en önemlisi vergi sisteminde yapılan düzenlemedir.

Bu çalışmada, XIX. yüzyılda Çankırı sancağına bağlı önemli kaza merkezlerinden biri olan Çerkeş'in 1261 tarihindeki ekonomik durumu ortaya konulmaktadır.

XIX. yüzyıl ortalarında Çerkeş kazasının ekonomisi tarım ve hayvancılı̆ga dayanmaktadır. Gerek kazanın merkezinde ve gerekse kazanın köy yerleşim yerlerinde halk zirai faaliyet yaparak hayatını sürdürmektedir. Ancak zirai faaliyet yanında daha ziyade günlük hayatta hayvani gıda ve diğer bazı ihtiyaçlarını karşıllamak gayesiyle iklim ve arazi şartlarını dikkate alarak büyükbaş ve kü̧̈ükbaş hayvan da beslemektedir. Yürütülen tüm ekonomik faaliyetler neticesinde Çerkeş kazasında 1261/1845 yılında elde edilen toplam 469953 kuruş temettüat gelirinden 181.171 kuruş vergi tahakkuk ettirilmiş̧ir.

Tanzimat dönemine damgasını vuran en önemli konulardan birisi Temettüat tahrir çalışmalarıdır. Temettüat tahrir çalışması uygulamalarının yapıldığı sancak merkezlerinden birisi Çankırı sancă̆ıdır. Bu çalışmada Çankırı'nın Çerkeş ilçesinde düzenlenen Temettüat tahrir uygulaması ekonomik yönden incelenecektir.

Anahtar Kelimeler: Çerkeş Temettüat, Temettüat uygulaması, Osmanlı'da ihtisap

\section{Abstract}

Ottoman Empire tried to make significant changes in political, social and economic fields in XIX. century. The most important innovation in the economic area was "tax system" in this period.

Economic situation of Çerkeş that was a town in Çankırı in 1261 is revealed in this study. Economy of Çerkeş depended on agriculture and livestock breeding in XIX. Century. Public in the both center and villages of Çerkeş operated agricultural activities. At the same time, public who took into account the climate and terrain conditions fed cattle and sheep so as to provide animal food and other needs in daily life. As a result of all the economic activities, Çerkeş in 1261/1845 obtained temettuat income that was 469953 kuruş and the tax collected was 181171 kuruş in temettuat income by Ottoman Empire.

One of the most important issues in Tanzimat period was Temettüat Tahrir books. Çankırı was one of the centers of sanjaks where the temettüat tahrir studies were implemented. Temettüat tahrir implemented in Çerkeş town of Çankırı will be analyzed economically in this study.

Keyword: Çerkeş Temettüat, Temettüat implemented, Ihtisap in Ottoman Empire

\footnotetext{
*Yrd. Doç. Dr.; Çankırı Karatekin Üniversitesi Ögretim Uyesi, ahmetyurtseven59@ gmail.com
} 


\section{GİRIŞ}

Osmanlı Devletinde, Tanzimat'ın ilanı ile birlikte devletin yeniden yapılandırılması konusunda önemli çalışmalar yapılmıştır. Tanzimat Fermanı'nda da özetle bahsedilen söz konusu çalışmaları siyasi, sosyal, kültürel ve ekonomik başlıkları altında toplamak mümkündür.

XVII. ve XVIII. yüzyıllar Osmanlı Devleti için arzu edilmeyen ve sıkıntıların tedricen arttığg bir dönemdir. Tanzimat Fermanı ile duruma el konulmuş ve çok yönlü 1slahatlara teşebbüs edilmiştir. Devlet kurumları tüm fonksiyonlarıyla gözden geçirilmiştir. Böylece hem devletin, hem de halkın nefes alması sağlanmıştır.

XIX. yüzyılda Osmanlı siyasi idaresinin devlete dinamizm vermek gayesiyle teşebbüste bulunduğu önemli yeniliklerden birisi temettüat tahrir çalışmasıdır. Tanzimat Fermanı'nın uygulama alanı bulduğu Osmanlı vilayetlerinde düzenlenen Temettüat tahrir çalışması, devletin mali sıkıntısını, bilhassa devletin yapacağı yeniliklerin finansman ihtiyacını karşılayabilmek maksadıyla yapılan çalışmaların altyapısıdır. Çünkü bu çalışmayla devlet vatandaşın nüfus ve vergi verme potansiyelini ölçmek istemiştir.

Osmanlı Devleti'nin son döneminde ekonomik faaliyetler sonucunda elde edilen kazançlardan(üretilen ürün üzerinden, meslek ve sanatkârlıktan) alınan vergiler birleştirilerek temettü vergisi adıyla "kazanca göre vergi" ilkesi hayata geçirilmeye çalışılmıştır. Tanzimat'ın uygulanacağı eyaletlerde Tanzimat Fermanı'nın ilanıyla hane reislerinin ilgili kayıtları tutulmuş ve elde edilen tüm bilgilerin kaydedildiği temettüat defterleri oluşturulmuştur. Çerkeş kazasına ait Çerkeş temettüat defteri de böyle bir çalışmanın ürünüdür; bu çalışmada söz konusu defterin ekonomik yönü ele alınmıştır.

Çalışmamızda önce Çerkeş kasabasının tarihi hakkında kısa bilgi verildi. Sonraki başlık altında temettüat defterleri ve temettüat tahrirleri ele alındı. Daha sonra, Çerkeş Kazasına ait düzenlenmiş olan 1261/1845 tarihli Çerkeş temettüat defterine göre Çerkeş kazasının XIX. yüzyılın ortalarındaki ekonomik durumu bu maksatla oluşturduğumuz tablolar yardımıyla incelendi.

\section{TARIHHTEN GÜNÜMÜZE ÇERKEŞ}

Osmanlı Devleti'nde Tanzimat'ın uygulandığg sancak merkezlerinden olan Çankırı'nın önemli yerleşim yerlerinden biri Çerkeş kaza merkezidir. Kuruluş tarihi oldukça eski olup Hititler'e kadar uzanmaktadır. Önemli yol güzergâhında yer almakta ve bu konumunu tarihte olduğu gibi günümüzde de korumaktadır. İlçe merkezinin ortasından demiryolunun geçmesi de önemli bir ayrıcalıktır.

Köklü bir geçmişe sahip olan Çerkeş, Malazgirt Zaferi’ne müteakip yaklaşık 10 yıl gibi kısa bir zaman diliminde Emir Karatekin (Karatigin) tarafından fethedilmiş daha sonra Çankırı'nın önemli kaza merkezlerinden biri haline gelmiştir.

\section{TEMETTÜAT TAHRİRLEİ ve TEMETTÜAT VERGISİ}

Osmanlı Devletinde mali reform düşüncesi, XVI. yüzyılın ikinci yarısından itibaren hep gündemde olmuştur. Bu yönde pek çok gayret sarf edilmiş, bazen akamete uğrasa da her fırsatta çeşitli girişimlerde bulunulmuştur. Fakat her teşebbüsten de çeşitli dersler çıkarılmış 
ve aynı hatalara düşülmemesine dikkat edilmiştir. Nihayet oldukça kapsamlı 1slahatları başlatmış olan III. Selim'i takip eden II. Mahmut aynı kararlılıkla çalışmalara devam etmiş;; önemli projelere de imza atmıştır. Mesela ekonomik yönden en önemli çalışmaları arasında İltizamla yönetilen hazine gelirlerinin doğrudan tahsil edilmesini sağlaması, vergi ayarlamasına gidilmesi ve bunun alt yapısı olan temettüat tahrir çalışmasını hazırlayarak uygulama safhasına getirmesini zikredebiliriz.

1295 'te tahta çıan Abdülmecit, II. Mahmut'un vefatıyla uygulamaya konulamayan çalışmalarını aynı kararlılıkla devam ettirdi. Önce 3 Kasım 1839'da Tanzimat Fermanını ilan ederek çalışmalara başladı. Hiç vakit kaybetmeden Hüdavendigar ve Gelibolu sancaklarında uygulaması yapılan temettüat tahrir çalışmasını, 1840 yılının ilk aylarından itibaren başlattı. İlgili nizamnamelerle halkı ve muhassıl denen yeni vergi memurlarını aydınlattı.

Muhassılların Tanzimat Fermanı'nın uygulandığı tüm yerleşim yerlerinde yapmış oldukları bu çalışmaya "Temettüat Tahrir Çalışması" denir. Bu çalışmalar esnasında hane bazında mal-mülk sayımı yapılmış, kimlik bilgileriyle beraber hane reislerinin gelirleri, vergileri belli bir düzen dâhilinde kayda geçirilmiştir. Sancaklara göre düzenlenmiş olan bu defterlere "Temettüat Tahrir Defterleri" veya kısaca "Temettüat Defterleri” denir.

XIX. yüzyılın ilk yarısında düzenlenmiş olan "Temettüat Defterleri” Başbakanlık Osmanlı Arşivi'nde bulunmaktadır. 1248(1833), 1256(1840), 1260 (1845) tarihlerini taşıyan Temettüat defterleri, düzenlendiği dönemin sosyo-ekonomik tarihine 1 şık tutmaktadır. ${ }^{1}$ Bu defterlerden birisi de 1261 (1845) tarihli ML. VRD. TMT. d kodlu ve 00666 sıra nolu Çerkeş Temettüat defteridir.

Temettü vergisi, Osmanlı Devletinin son döneminde vergi mükelleflerinin kazançları dikkate alınarak konulmuş bir vergidir. ${ }^{2}$ Fakat tarihi çok eskilere kadar uzanan bu verginin aslı ihtisap vergisi olup, kurumun adı da "Hisbe Teşkilatı" dır. ${ }^{3}$

"Asr-1 Saadet" ten beri İslam ülkelerinde uygulanmakta olan ihtisap vergisi, Osmanlılarda Osman Gazi zamanında bac-1 bâzar ile başlamış ve bu işle görevli memura da muhtesip denilmiştir. İște temettü vergisinin aslı da bu vergidir.

Osmanlı Devleti'nde oldukça uzun süre devam eden vergilerden biri olan ihtisap vergisi, zamanla halka ağır geldiği için huzursuzlukların kaynağı olmaya başlayınca gerek başkentte ve gerekse taşrada temel şikâyet konuları arasında yer almıştır. Toplum üzerinde oluşturduğu psikolojik etkiyi firsat bilen bazı kimselerin isyanla sonuçlanacak şekilde meseleyi el altından körükleyerek bundan istifade etmeleri devlete sıkıntı veriyordu. Nihayet şikâyetlere sebep olan olaylara son vermek için ihtisap nazır ve memurlarının uygunsuz davranışları yüzünden vazifeden alınmaları pek fazla bir şey değiştirmeyince söz konusu verginin bazı yerlerde yürürlükten kaldırılmasına karar verilmiştir. Önce 16

\footnotetext{
${ }^{1}$ Başbakanlık Osmanlı Arşivi Daire Başkanlığı, Osmanlı İdaresinde Kıbrıs (Nüfusu-Arazi Dağılımı ve Türk Vakıfları), Başbakanlık Devlet Arşivleri Genel Müdürlüğü Osmanlı Arşivi Daire Başkanlığı Yayınları, Ankara, 2000, s. 68;

KÜTÜKOĞLU, Mübahat S., "Osmanlı Sosyal ve İktisadi Tarihi Kaynaklarından Temettü Defterleri”, Belleten, Türk Tarih Kurumu Yayınları, Ankara, 1995, s. 396

2 Parlatır, İsmail, Osmanlı Türkçesi Sözlüğü, Yargı Yayınları, Ankara, 2006, S.1682

${ }^{3}$ Kazıcı, Ziya, Osmanlılarda İhtisap Müessesesi (Ekonomik, Dini Ve Sosyal Hayat), İstanbul: Kültür Basın Ve Yayın Birliği Yayınları, İstanbul, 1987, s. 20.
} 
Cemaziye'levvel 1254/ 7 Ağustos 1838 tarihli Takvim-i Vekayi'deki fermana göre, Hüdavendiğar ve Gelibolu sancaklarında tamamen, İstanbul'da ise kısmen kaldırılmıştı. Ancak alınan çeşitli tedbir ve çarelerden sonuç alınamayınca 2 Zilka'de 1271/ 16 Ağustos 1854 tarihinde ihtisap vergisi tamamen kaldırılmıştır. ${ }^{4}$

"XIX. Yüzyılın Ortalarında Çerkeş Kazasının Ekonomik Durumu” başlığını taşıyan bu çalışmanın temel veri kaynağını 1261 (1845) tarihli ML. VRD. TMT. d kodlu ve 00666 sıra nolu temettüat defteri teşkil etmektedir.

\section{III. ÇERKEŞ KAZASININ EKONOMIKK DURUMU}

XIX. yüzyılın ortalarında Çerkeş kazasının genelinde hane reislerine ait mal varlığını ve dağılımını üç ana grupta toplayabiliriz. Bunlar yetiştirilen hayvanların çeşitleri ve dağılımı, tarım alanları ve dağlımı, diğer mal varlıkları ve dağılımıdır.

Kaynağımızda her yerleşim yerinde hane numarası altında şahsın kimliğine ait bilgiler uzunca bir cümle halinde ifade edilmektedir. Bu satırın altında vergi mükellefinin tüm mal varlıklarının dökümü yapılmakta ve sonunda yekûn temettüata yer verilmektedir. Mamafih her yerleşim biriminin sonunda yer alan toplam temettüatlardan hareketle yaptı̆̆ımız ayrı bir işlem sonucunda bazı yerleşim birimlerinin toplam temettüatlarında farklı sonuçlar elde ettik. Fakat bu çalışmada ilk sonucu kullanmayı tercih ettik. Çerkeş kazasının 1260 yılındaki toplam mal varlıklarını incelemeye çalışalım.

\section{Hayvancilık}

İnsanoğlunun en eski geçim kaynaklarından birisi hayvancıllktır. Dün olduğu gibi günümüzde de insanın ekonomik gelirleri arasında önemli bir paya sahip bulunmaktadır. İnsanların günlük hayatlarında hayvansal ürünler dediğimiz et, süt, yoğurt, deri, yün, hayati önem taşımaktadır. Bu yüzden Osmanlı hane halkı ihtiyaçlarının karşılanması için arazi şartlarına göre birkaç inek ve birkaç koyun keçi beslemeye çalışmıştır. Ayrıca diğer ihtiyaçlarının karşılanması için yani gerek binek olarak, gerekse taşımacılıkta ve çift sürmede faydalanmak üzere yerine göre büyük baş hayvanlara da ağılında yer vermiştir.

XIX. yüzyılın ortalarında Çerkeş kasabasının hem şehir merkezinde ve hem de köy yerleşim yerlerinde hayvancılık yaygın olarak yapılmaktadır. Nitekim bu durum ayrı ayrı tablolar halinde yansıtılmıştır. Çerkeş kasabası dahilinde toplam 2602 büyükbaş hayvandan 382 büyükbaş hayvan, şehir merkezini oluşturan mahallelerde meskûn olan hanelere aittir. Kalanı da büyüklü küçüklü köylerde yaşayan hane reislerine ait bulunmaktadır.

Büyükbaş Hayvancılık: H. 1261 tarihli Çerkeş Temettüat Defterindeki verilere göre mahallelerin büyükbaş hayvancılık durumu Tablo 6/a'da görülmektedir. Nefs-i Çerkeş' in mahallelerine göre büyükbaş hayvanlar adedi itibariyle sırasıyla en fazla sağman inek (108), karasığır öküzü (94), boz inek (64), sağman camış (48), camış öküzü (22), boz sağman inek (21) yer almaktadır. Sağman ineğe en fazla sahip olan mahalle Karalar Mahallesi, en az sağman ineğe sahip olan mahalle de Okçular Mahallesidir. Yine Tablo 6/a'da görüldüğü gibi karasığır cinsi büyük baş hayvanlar sayı itibariyle en fazla durumdadır.

\footnotetext{
${ }^{4}$ Kazıc1, Ziya, a.g.e., s. 188-192.
} 


\begin{tabular}{|c|c|c|c|c|c|c|c|c|c|c|c|c|c|c|}
\hline \multicolumn{15}{|c|}{ Tablo 6/a. Mahallelerin Büyükbaş Hayvancılık Durumu (Ra's) } \\
\hline $\begin{array}{l}\underset{Z}{z} \\
\stackrel{\pi}{=} \\
\end{array}$ & 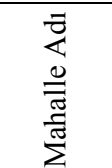 & 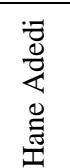 & 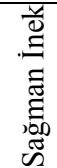 & 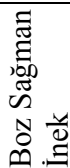 & 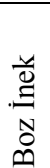 & $:$ : & 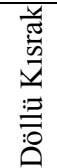 & 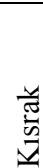 & 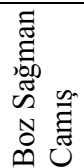 & 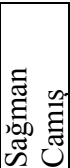 & 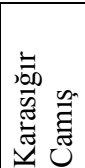 & 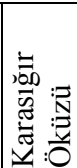 & 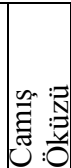 & 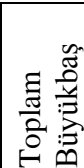 \\
\hline 1 & Karalar & 109 & 65 & 6 & 1 & 1 & 1 & 1 & 1 & 14 & 0 & 22 & 8 & 120 \\
\hline 2 & Okçular & 83 & 8 & 4 & 60 & 3 & 2 & 0 & 1 & 13 & 2 & 14 & 0 & 107 \\
\hline 3 & Kurtlar & 75 & 12 & 1 & 1 & 2 & 3 & 0 & 0 & 4 & 2 & 30 & 4 & 59 \\
\hline 4 & İdris & 102 & 23 & 10 & & 2 & 3 & 0 & 2 & 17 & 0 & 28 & 10 & 97 \\
\hline & $\begin{array}{l}\text { Senel } \\
\text { oplam }\end{array}$ & 369 & 108 & 21 & 64 & 8 & 9 & 1 & 4 & 48 & 3 & 94 & 22 & 382 \\
\hline
\end{tabular}

Nefs-i Çerkeş'in tüm mahalleleri açısından bakıldı̆̆ında toplam büyükbaş hayvan sayısı ile ilk sırayı toplam120 adet büyükbaş hayvanla Karalar Mahallesi alırken ikinci sırayı da 107 adet büyükbaş hayvanla Okçular Mahallesi almaktadır. Toplam büyükbaş hayvanın en düşük olduğu mahalle de 59 adet büyükbaş hayvanla Kurtlar Mahallesi'dir.

\begin{tabular}{|c|c|c|c|c|c|c|c|c|c|c|c|c|c|c|}
\hline \multicolumn{15}{|c|}{ Tablo 6/b. Çerkeş Köylerinin Büyükbaş Hayvancılık Durumu (Ra's) } \\
\hline 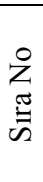 & 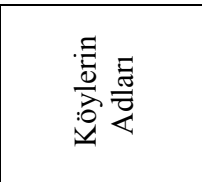 & 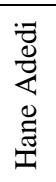 & 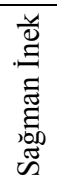 & 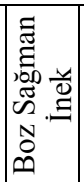 & 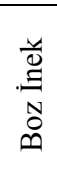 & 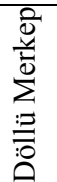 & 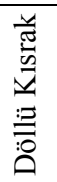 & 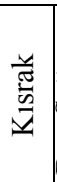 & 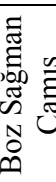 & 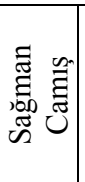 & 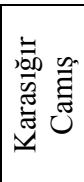 & 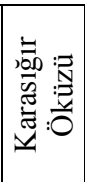 & 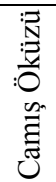 & 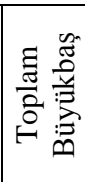 \\
\hline 1 & Bozoğlu & 54 & 45 & 21 & 2 & 1 & 1 & 0 & 0 & 14 & 0 & 44 & 8 & 136 \\
\hline 2 & Ahur & 21 & 17 & 14 & 0 & 0 & 0 & 0 & 0 & 0 & 0 & 26 & 2 & 59 \\
\hline 3 & Yalaközü & 15 & 23 & 12 & 0 & 0 & 8 & 2 & 0 & 3 & 0 & 22 & 2 & 72 \\
\hline 4 & Yalakçukuranı & 25 & 37 & 12 & 4 & 0 & 18 & 0 & 1 & 20 & 0 & 22 & 2 & 116 \\
\hline 5 & Saçak & 55 & 52 & 32 & 3 & 7 & 9 & 0 & 0 & 18 & 0 & 70 & 6 & 197 \\
\hline 6 & Kara Mustafa & 14 & 25 & 13 & 1 & 8 & 9 & 0 & 0 & 5 & 0 & 26 & 2 & 89 \\
\hline 7 & Kadıözü & 22 & 24 & 5 & 5 & 13 & 0 & 0 & 0 & 0 & 0 & 20 & 0 & 67 \\
\hline 8 & Eymür & 9 & 5 & 0 & 4 & 0 & 3 & 0 & 0 & 0 & 0 & 10 & 0 & 22 \\
\hline 9 & Hacılar & 22 & 31 & 4 & 7 & 0 & 9 & 0 & 0 & 4 & 0 & 22 & 4 & 81 \\
\hline 10 & Aliözü & 21 & 27 & 0 & 15 & 11 & 4 & 0 & 0 & 0 & 0 & 34 & 0 & 91 \\
\hline 11 & Çalcaviran & 18 & 27 & 0 & 14 & 4 & 7 & 0 & 0 & 0 & 0 & 24 & 0 & 76 \\
\hline 12 & Okçuk & 14 & 18 & 0 & 11 & 9 & 1 & 0 & 0 & 0 & 0 & 24 & 0 & 63 \\
\hline 13 & Gelik & 6 & 4 & 0 & 1 & 2 & 1 & 0 & 0 & 1 & 0 & 6 & 6 & 21 \\
\hline 14 & Şeyh Doğan & 23 & 20 & 0 & 10 & 1 & 7 & 0 & 0 & 0 & 0 & 0 & 0 & 38 \\
\hline 15 & Kınık & 6 & 10 & 0 & 4 & 2 & 1 & 0 & 0 & 0 & 0 & 10 & 0 & 27 \\
\hline 16 & Kızıllar & 8 & 11 & 0 & 6 & 4 & 2 & 0 & 0 & 0 & 0 & 10 & 0 & 33 \\
\hline 17 & Bedil & 15 & 24 & 0 & 11 & 8 & 7 & 0 & 0 & 3 & 0 & 28 & 0 & 81 \\
\hline 18 & Bayındır & 7 & 6 & 0 & 4 & 4 & 2 & 0 & 0 & 0 & 0 & 6 & 2 & 24 \\
\hline 19 & Kadıköy & 12 & 7 & 0 & 1 & 4 & 2 & 0 & 0 & 1 & 0 & 20 & 0 & 35 \\
\hline 20 & Çölmekci & 12 & 8 & 0 & 3 & 1 & 0 & 0 & 0 & 0 & 0 & 8 & 2 & 22 \\
\hline 21 & Dikenlü & 15 & 23 & 0 & 6 & 9 & 1 & 0 & 0 & 2 & 0 & 12 & 3 & 56 \\
\hline 22 & Karaköçek & 13 & 20 & 0 & 8 & 2 & 0 & 0 & 0 & 1 & 0 & 20 & 2 & 53 \\
\hline 23 & Yortan & 15 & 13 & 0 & 8 & 7 & 0 & 0 & 0 & 1 & 0 & 24 & 0 & 53 \\
\hline 24 & Kalfakolu & 8 & 7 & 0 & 3 & 0 & 0 & 0 & 0 & 0 & 0 & 12 & 0 & 22 \\
\hline 25 & Ağaköy & 16 & 15 & 0 & 8 & 8 & 0 & 0 & 0 & 1 & 0 & 20 & 2 & 54 \\
\hline 26 & Saraycık & 25 & 33 & 0 & 19 & 15 & 5 & 0 & 0 & 0 & 0 & 0 & 0 & 72 \\
\hline 27 & Akhasan & 10 & 7 & 0 & 5 & 2 & 0 & 0 & 0 & 0 & 0 & 16 & 2 & 32 \\
\hline
\end{tabular}




\begin{tabular}{|c|l|c|c|c|c|c|c|c|c|c|c|c|c|c|}
28 & Yumaklı & 24 & 21 & 0 & 12 & 0 & 1 & 0 & 0 & 0 & 0 & 30 & 0 & 64 \\
\hline 29 & Yoncalı & 8 & 8 & 1 & 3 & 1 & 2 & 0 & 0 & 1 & 0 & 6 & 4 & 26 \\
\hline 30 & Bozcaarmud & 6 & 8 & 0 & 4 & 0 & 0 & 0 & 0 & 0 & 0 & 12 & 0 & 24 \\
\hline 31 & Kısaç & 15 & 20 & 0 & 10 & 6 & 2 & 0 & 0 & 4 & 0 & 18 & 4 & 64 \\
\hline 32 & Dağçukuranı & 9 & 16 & 0 & 7 & 1 & 0 & 0 & 0 & 1 & 0 & 16 & 0 & 41 \\
\hline 33 & Elpirek & 3 & 6 & 0 & 2 & 0 & 0 & 0 & 0 & 0 & 0 & 4 & 0 & 12 \\
\hline 34 & Yakublar & 5 & 11 & 0 & 5 & 1 & 4 & 0 & 0 & 1 & 0 & 8 & 0 & 30 \\
\hline 35 & Ödülller & 2 & 5 & 0 & 2 & 2 & 0 & 0 & 0 & 0 & 0 & 4 & 0 & 13 \\
\hline 36 & Virancık & 2 & 7 & 0 & 2 & 2 & 0 & 0 & 0 & 0 & 0 & 4 & 0 & 15 \\
\hline 37 & Tirbaş1 & 19 & 19 & 0 & 9 & 7 & 2 & 0 & 0 & 1 & 0 & 20 & 6 & 64 \\
\hline 38 & Viran & 39 & 60 & 0 & 27 & 3 & 4 & 0 & 0 & 6 & 0 & 60 & 2 & 162 \\
\hline \multicolumn{2}{|c|}{ Genel Toplam } & 613 & 720 & 114 & 246 & 145 & 112 & 2 & 1 & 88 & 0 & 718 & 61 & 2207 \\
\hline
\end{tabular}

Büyükbaş hayvanlardan inek cinslerinin süt ürünlerinden faydalanmak için beslenildiği bilinmektedir. Bu tür hayvanların kasaba merkezinde toplamı 245 baş olup bunun 193 başı karasığır ineği ve 52 başı da camış ineğidir.

Mezkûr defterden anlaşıldığına göre 1260'lı yıllarda gerek karası̆̆ır gerekse camış türünün erkek olanlarından, eneme yoluyla öküz yapılarak güçlerinden istifade edilmekteydi. Bu tür hayvanların kasaba merkezi itibari ile toplamı 116 baş olup bunun 94 başı karasığır öküzüdür. Bu yöntem günümüzde de geçerliliğini korumaktadır. Camış ineği besiciliğinin kaymak üretiminde oldukça önemli yer tuttuğu bilinmektedir. Bölgede camış türü hayvancılığının yapılmasının nedenlerinden biri de bölgenin bu türün yaşamasına müsait olmasındandır. Çünkü camış türü hayvanlar su ve bataklığı çok sevmektedir.

Tüm köylere ait büyükbaş hayvancılık durumunu rakamlarla Tablo 6/b'de görmekteyiz. Toplam 38 köye ait büyükbaş hayvanlar sırasıyla (baş olarak) sağmal inek (720), karasığır öküzü (718), boz inek (246), döllü merkep (145), boz sağmal inek (114), sağmal camış (88), bulunmaktadır. XIX yüzyılın ortalarında Çerkeş Kasabasının tüm köylerinde toplam olarak 2.207 büyükbaş hayvan bulunmaktayd1. Bu rakamın 1.080 baş1 karasığır inek türüne ait olup 89 baş camış ineği bunun dışındadır.

\begin{tabular}{|c|c|c|c|c|c|c|c|c|c|c|c|c|c|}
\hline \multicolumn{14}{|c|}{ Tablo 6/c. Çiftliklerin Büyükbaş Hayvancilık Durumu (Ra's) } \\
\hline 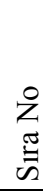 & 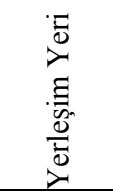 & 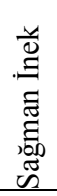 & 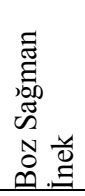 & $\begin{array}{l}\stackrel{\ddot{\Xi}}{\Xi} \\
\stackrel{N}{0} \\
\ddot{\emptyset}\end{array}$ & 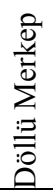 & 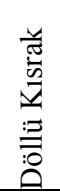 & 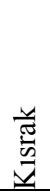 & 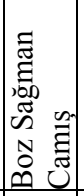 & 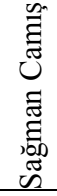 & 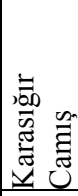 & 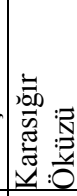 & 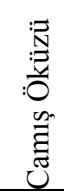 & 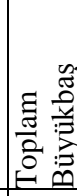 \\
\hline 1 & $\begin{array}{c}\text { Çiftlik } \\
\text { Basmul }\end{array}$ & 4 & 0 & 2 & 1 & 1 & 0 & 0 & 2 & 0 & 0 & 2 & 12 \\
\hline
\end{tabular}

Binek hayvanı olarak şehir merkezinde toplam olarak 9 merkep ve 10 kısrak bulunmaktadır. Binek hayvanların bu dağlımı da Tablo 6/a'da görülmektedir. 


\begin{tabular}{|c|c|c|c|c|c|c|c|c|}
\hline \multicolumn{9}{|c|}{ Tablo 7/a. Mahallelerin Küçükbaş Hayvancılık Durumu (Ra's) } \\
\hline 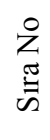 & $\begin{array}{l}\stackrel{0}{\bar{\sigma}} \\
\text { 胥 } \\
\Sigma\end{array}$ & 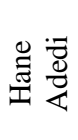 & 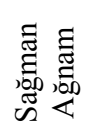 & 周 营 & 总莺 & 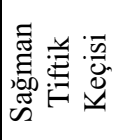 & 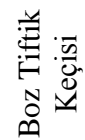 & 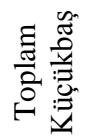 \\
\hline 1 & Karalar & 109 & 65 & 26 & 10 & 25 & 0 & 126 \\
\hline 2 & Okçular & 83 & 40 & 6 & 39 & 15 & 0 & 100 \\
\hline 3 & Kurtlar & 75 & 125 & 58 & 0 & 75 & 15 & 273 \\
\hline 4 & İंdris & 102 & 78 & 39 & 0 & 67 & 0 & 184 \\
\hline \multicolumn{2}{|c|}{ Genel Toplam } & 369 & 308 & 129 & 49 & 182 & 15 & 683 \\
\hline
\end{tabular}

Kasabaya ait yerleşim merkezlerinden biri olan çiftlikte (baş olarak) 4'ü sağmal inek, 2'si boz inek olmak üzere toplam 6 inek, 2 sağmal camış, 2 camış öküzü; ve binek hayvanı olarak da biri merkep diğeri de kısrak olmak üzere 2 baş bulunmaktadır (Tablo 6/c). Kısaca çiftlik merkezinde toplam olarak 12 adet büyükbaş hayvan çiftlik sahibine hizmet vermektedir.

\begin{tabular}{|c|c|c|c|c|c|c|c|c|}
\hline \multicolumn{9}{|c|}{ Tablo 7/b. Köylerin Küçükbaş Hayvancılık Durumu (Ra's) } \\
\hline 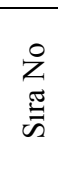 & 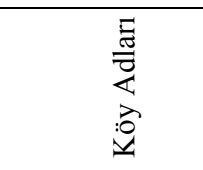 & 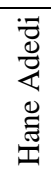 & 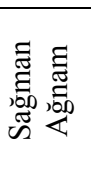 & 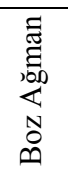 & 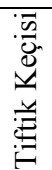 & 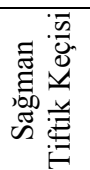 & 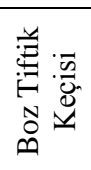 & 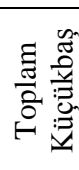 \\
\hline 1 & Bozoğlu & 54 & 42 & 16 & 6 & 34 & 0 & 98 \\
\hline 2 & Ahur & 21 & 25 & 10 & 0 & 33 & 0 & 68 \\
\hline 3 & Yalaközü & 15 & 16 & 7 & 0 & 7 & 0 & 30 \\
\hline 4 & Yalakçukuranı & 25 & 212 & 86 & 5 & 143 & 5 & 451 \\
\hline 5 & Saçak & 55 & 176 & 72 & 0 & 111 & 30 & 389 \\
\hline 6 & Kara Mustafa & 14 & 68 & 28 & 0 & 40 & 0 & 136 \\
\hline 7 & Kadıözü & 22 & 116 & 45 & 0 & 71 & 7 & 239 \\
\hline 8 & Eymür & 9 & 43 & 27 & 0 & 10 & 0 & 80 \\
\hline 9 & Hacılar & 22 & 73 & 0 & 28 & 0 & 39 & 140 \\
\hline 10 & Aliözü & 21 & 107 & 45 & 0 & 78 & 0 & 230 \\
\hline 11 & Çalcaviran & 18 & 218 & 110 & 0 & 146 & 52 & 526 \\
\hline 12 & Okçuk & 14 & 10 & 4 & 0 & 10 & 0 & 24 \\
\hline 13 & Gelik & 6 & 55 & 20 & 0 & 25 & 15 & 115 \\
\hline 14 & Şeyh Doğan & 23 & 184 & 69 & 0 & 64 & 43 & 360 \\
\hline 15 & Kinık & 6 & 17 & 0 & 0 & 10 & 0 & 27 \\
\hline 16 & Kizillar & 8 & 83 & 22 & 0 & 35 & 13 & 153 \\
\hline 17 & Bedil & 15 & 61 & 28 & 0 & 40 & 13 & 142 \\
\hline 18 & Bayındır & 7 & 25 & 10 & 0 & 15 & 8 & 58 \\
\hline 19 & Kadıköy & 12 & 50 & 15 & 0 & 25 & 8 & 98 \\
\hline 20 & Çölmekci & 12 & 21 & 10 & 0 & 7 & 0 & 38 \\
\hline 21 & Dikenlü & 15 & 40 & 10 & 0 & 28 & 8 & 86 \\
\hline 22 & Karaköçek & 13 & 53 & 17 & 0 & 30 & 10 & 110 \\
\hline 23 & Yortan & 15 & 20 & 5 & 0 & 37 & 5 & 67 \\
\hline 24 & Kalfakolu & 8 & 5 & 0 & 0 & 10 & 5 & 20 \\
\hline 25 & Ağaköy & 16 & 70 & 35 & 0 & 48 & 15 & 168 \\
\hline 26 & Saraycik & 25 & 195 & 81 & 0 & 118 & 43 & 437 \\
\hline 27 & Akhasan & 10 & 46 & 5 & 0 & 36 & 0 & 87 \\
\hline 28 & Yumaklı & 24 & 65 & 30 & 0 & 32 & 10 & 137 \\
\hline 29 & Yoncali & 8 & 60 & 35 & 0 & 35 & 40 & 170 \\
\hline
\end{tabular}




\begin{tabular}{|l|l|c|c|c|c|c|c|c|}
30 & Bozcaarmud & 6 & 30 & 0 & 5 & 15 & 3 & 53 \\
\hline 31 & Kisaç & 15 & 166 & 45 & 0 & 123 & 25 & 359 \\
\hline 32 & Dağçukuranı & 9 & 57 & 23 & 0 & 50 & 0 & 130 \\
\hline 33 & Elpirek & 3 & 20 & 5 & 0 & 17 & 6 & 48 \\
\hline 34 & Yakublar & 5 & 40 & 10 & 0 & 15 & 5 & 70 \\
\hline 35 & Ödülller & 2 & 25 & 20 & 0 & 30 & 10 & 85 \\
\hline 36 & Virancık & 2 & 30 & 10 & 0 & 10 & 8 & 58 \\
\hline 37 & Tirbaş1 & 19 & 98 & 41 & 0 & 55 & 10 & 204 \\
\hline 38 & Viran & 39 & 75 & 23 & 0 & 40 & 18 & 156 \\
\hline \multicolumn{2}{|l|}{ Genel Toplam } & 613 & 2697 & 1019 & 44 & 1633 & 454 & 5847 \\
\hline
\end{tabular}

Küçükbaș Hayvanlar: Çerkeş kasabasında küçükbaş hayvanın iki türüne rastlanılmaktadır. Bunlar koyun ve keçi türleridir. Küçükbaş hayvancılıkta bölgenin doğal yapısı önemlidir. Kasaba genelinde küçükbaş hayvanların türleri itibariyle genel dağılımı çiftlik, köyler ve kasaba merkezi halinde üç ayrı tablo (Tablo 7/a. Mahallelerin küçükbaş hayvancılık durumu (ra's), Tablo 7/b. Köylerin küçükbaş hayvancılık durumu (ra's) ve Tablo 7/c. Çiftliklerin kü̧̧ükbaş hayvancılık durumu (ra's)) halinde görülmektedir. Söz konusu tablolara göre kasaba genelinde küçükbaş hayvanlar arasında en fazla rakamı 3.040 baş ile sağmal ağnam, 1.833 baş ile sağmal tiftik keçisi, 1.163 baş ile boz ağnam (koyun), 483 baş ile boz tiftik keçisi ve 93 baş ile tiftik keçisi oluşturmaktadır.

Kasabanın tüm yerleşim yerleri içerisinde 273 baş ile en fazla küçükbaş hayvan Kurtlar Mahallesi'nde bulunmaktadır. Şehir merkezinde bulunan mahallelerde küçükbaş hayvan adedi toplamda 683 rakamına ulaşmaktadır. Tablo 7/a'da görüldügü gibi bunun 437 başı koyun, 246 başı da keçiden oluşmaktadır. Küçükbaş hayvanların sağman olanları sırasıyla, 125 baş sağman ağnam ile Kurtlar Mahallesi, 78 baş ile İdris Mahallesi, 65 baş ile Karalar Mahallesi, 40 baş ile Okçular Mahallesi; sağmal tiftik keçisi sırasıyla, 75 baş ile Kurtlar Mahallesi, 67 baş ile İdris Mahallesi, 25 baş ile Karalar Mahallesi ve 15 baş ile Okçular Mahallesi gelmektedir.

Hayvancilıkta boz (bazı bölgelerde ise yoz) kavramı olarak ifade edilen terim, yavrusu olmayan kısır hayvan demektir. Küçükbaş hayvancılığın Çerkeş Kasabasının köy yerleşim yerleri arasındaki dağılımı Tablo 7/b'de görüldüğü gibi; 38 köyde toplam olarak 2.697 baş sağmal ağnam ve bunu 1.633 baş ile sağmal tiftik keçisi izlemektedir. İlçenin bütün köylerinde ise toplam olarak 5.847 baş küçükbaş hayvan bulunmaktadır.

\begin{tabular}{|c|c|c|c|c|c|c|c|}
\hline \multicolumn{8}{|c|}{ Tablo 7/c. Çiftliklerin Küçükbaș Hayvancilık Durumu (Ra's) } \\
\hline $\begin{array}{l}\stackrel{0}{Z} \\
\stackrel{\pi}{G} \\
\tilde{n}\end{array}$ & 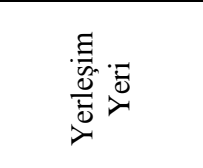 & 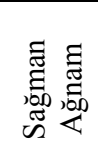 & 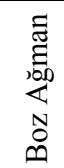 & 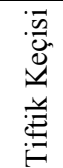 & 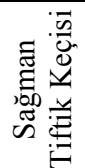 & 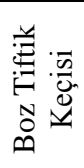 & 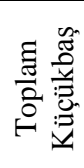 \\
\hline 1 & Çiftlik Basmul & 35 & 15 & 0 & 18 & 14 & 82 \\
\hline
\end{tabular}

Basmul çiftliğinin küçükbaş hayvancılık açısından durumu Tablo7/c'de verilmektedir. Toplam olarak 82 baş küçükbaş hayvanın bulunduğu bu çiftlikte en fazla koyun yetiştirilmektedir. Bu koyunların da 35 başını sağmal ağnam teşkil etmektedir. Ayrıca 32 baş olan tiftik keçisinin de 18 başını sağmal tiftik keçisi oluşturmaktadır. 


\section{Arazi Dağlımı}

Çerkeş kazasının doğal yapısı zirai hayata ve hayvancılığa müsaittir. Kaza Ulusu Çayı'nın aktığı ovada kurulmuştur. Yağışlar daha ziyade kış aylarında görülmektedir. Yaz aylarında yağışın az olması dolayısı ile tarımsal faaliyet sulama ile yapılmaktadır. H.1260'lı yıllarda bölgede tarımsal faaliyetin yanında hayvancılık da yapılmaktaydı. Yöre arazisinin bir kısmının zayıf bir bitki örtüsü ile kaplı bulunması dolayısıyla halk arazisinin bir kısmını daha iyi verim alabilmek için sene boyu zirai faaliyet yapmayarak dinlendiriyordu. $\mathrm{Bu}$ şekilde arazinin dinlendirilmesine nadasa bırakma denilmektedir.

Mezru Tarla: Zirai faaliyet yapmaya elveriş̧i (ekili) tarım alanı demektir. Çerkeş kazasına ait temettuat defterinde de ekili dikili alanlar için kullanılmaktadır.

Temettüat defterlerinde tarım yapılan alanlar hakkında ayrıntılı bilgiler bulunmaktadır. Tarıma elverişli alanların ne kadarında tarımsal faaliyet yapıldığı ve ne kadarının da nadasa bırakıldığı öğrenilmektedir. Ekilebilir arazinin toplamı 17.625,5 dönümdür. Bunun 8.028,5 dönümü mezru, 9.586 dönümü gayri mezru ve 11 dönümü de çayır olarak kullanılmak üzere ayrılmıştır. Tablo 8/a, Tablo 8/b ve Tablo 8/c'lerde görüldüğü gibi temettüat defterindeki hane numaralarının toplamında hatalar yapılmış olduğunu tespit edilmiştir. Şöyle ki, hane numaraları verilirken bazen tekrar edilmiş, bazen hane numaraları atlanılmış, bazen de hane numarası verilmeyip 'bilahane' şeklinde yazılmalar olmuştur. Bu yüzden hanelerin hepsine numara verilmiş gibi kabul ederek toplam hane neticesi elde edilmiş ve bu yüzden ilgili tablolara numaralı hane yanında bir de elde edilen yerleşim yerlerinin toplam hane sayısını " netice" olarak ayrıca verilmiştir.

Çerkeş kasabası genelinde en büyük ekili alanlara sahip olan yerleşim birimleri sırasıyla 55 haneli Saçak karyesi, 39 haneli Viran karyesi ve Karalar Mahallesi gelmektedir. Bunlardan Saçak karyesi 676 dönümü gayri mezru, 556 dönümü mezru ve 2 dönümü çayır olmak üzere toplam 1.234 dönümlük alanı kapsamaktadır. Viran karyesi 546 dönümü gayri mezru, 527 dönümü mezru olmak üzere toplam 1.073 dönümlük alanı ve Karalar Mahallesi ise 626 dönümü gayri mezru, 410 dönümü mezru olmak üzere toplam 1.036 dönümlük bir alanı kapsamaktadır (Tablo 8/a, b).

\begin{tabular}{|c|l|c|c|c|c|c|c|}
\hline \multicolumn{7}{|c|}{ Tablo 8/a. Mahallerin Arazi Dă̆lımı (Dönüm) } \\
\hline $\begin{array}{c}\text { Sıra } \\
\text { No }\end{array}$ & Mahalle Adı & $\begin{array}{c}\text { Numaralı } \\
\text { Hane }\end{array}$ & Netice & $\begin{array}{c}\text { Mezru } \\
\text { Tarla }\end{array}$ & $\begin{array}{c}\text { Gayri Mezru } \\
\text { Tarla }\end{array}$ & Çayır & $\begin{array}{c}\text { Toplam } \\
\text { Arazi }\end{array}$ \\
\hline 1 & Karalar & 109 & 109 & 410 & 626 & 0 & 1036 \\
\hline 2 & Okçular & 84 & 83 & 292 & 238 & 0 & 530 \\
\hline 3 & Kurtlar & 77 & 75 & 337 & 338 & 0 & 675 \\
\hline 4 & İdris & 102 & 102 & 532 & 472 & 0 & 1004 \\
\hline \multicolumn{2}{|l|}{ Genel Toplam } & 372 & 369 & 1571 & 1674 & 0 & 3245 \\
\hline
\end{tabular}

Çerkeş'in kaza merkezindeki mahallelerin sahip oldukları toplam arazi miktarı dağılımı Tablo 8/a'da görülmektedir. Arazi büyüklüğü bakımından en fazla araziye sahip olan mahalle Karalar Mahallesi ve en az araziye sahip olan mahalle de Okçular Mahallesi'dir. 
Ahmet Yurtseven

\begin{tabular}{|c|c|c|c|c|c|c|c|}
\hline & & Tablo 8/b. & öylerin & enel Arazi Da & lımı (Dönüm) & & \\
\hline $\begin{array}{l}\text { Sira } \\
\text { No }\end{array}$ & Köy & $\begin{array}{c}\text { Numaralı } \\
\text { Hane }\end{array}$ & Netice & Mezru Tarla & $\begin{array}{c}\text { Gayri Mezru } \\
\text { Tarla }\end{array}$ & Çayır & $\begin{array}{c}\text { Toplam } \\
\text { Arazi }\end{array}$ \\
\hline 1 & Bozoğlu & 48 & 54 & 429 & 487 & 0 & 916 \\
\hline 2 & Ahur & 23 & 21 & 196 & 304 & 0 & 500 \\
\hline 3 & Yalaközü & 14 & 15 & 167 & 148 & 0 & 315 \\
\hline 4 & Yalakçukuranı & 25 & 25 & 248 & 308 & 4 & 560 \\
\hline 5 & Saçak & 57 & 55 & 556 & 676 & 2 & 1234 \\
\hline 6 & Kara Mustafa & 15 & 14 & 207 & 212 & 0 & 419 \\
\hline 7 & Kadıözü & 23 & 22 & 176 & 297 & 0 & 473 \\
\hline 8 & Eymür & 8 & 9 & 65,5 & 114 & 0 & 179,5 \\
\hline 9 & Hacilar & 19 & 22 & 208 & 217 & 1 & 426 \\
\hline 10 & Aliözü & 21 & 21 & 242 & 254 & 0 & 496 \\
\hline 11 & Çalcaviran & 18 & 18 & 210 & 309 & 2 & 521 \\
\hline 12 & Okçuk & 14 & 14 & 167 & 207 & 0 & 374 \\
\hline 13 & Gelik & 7 & 6 & 54 & 116 & 0 & 170 \\
\hline 14 & Şeyh Doğan & 24 & 23 & 174 & 301 & 0 & 475 \\
\hline 15 & Kinik & 6 & 6 & 72 & 103 & 0 & 175 \\
\hline 16 & Kizillar & 8 & 8 & 88 & 125 & 0 & 213 \\
\hline 17 & Bedil & 15 & 15 & 192 & 223 & 0 & 415 \\
\hline 18 & Bayındır & 8 & 7 & 89 & 69 & 2 & 160 \\
\hline 19 & Kadıköy & 12 & 12 & 149 & 159 & 0 & 308 \\
\hline 20 & Çölmekci & 9 & 12 & 80 & 159 & 0 & 239 \\
\hline 21 & Dikenlü & 17 & 15 & 146 & 229 & 0 & 375 \\
\hline 22 & Karaköçek & 13 & 13 & 155 & 164 & 0 & 319 \\
\hline 23 & Yortan & 16 & 15 & 189 & 223 & 0 & 412 \\
\hline 24 & Kalfakolu & 9 & 8 & 98 & 129 & 0 & 227 \\
\hline 25 & Ağaköy & 16 & 16 & 181 & 180 & 0 & 361 \\
\hline 26 & Saraycık & 22 & 25 & 258 & 278 & 0 & 536 \\
\hline 27 & Akhasan & 12 & 10 & 126 & 134 & 0 & 260 \\
\hline 28 & Yumaklı & 24 & 24 & 223 & 317 & 0 & 540 \\
\hline 29 & Yoncal1 & 7 & 8 & 72 & 64 & 0 & 136 \\
\hline 30 & Bozcaarmud & 7 & 6 & 72 & 73 & 0 & 145 \\
\hline 31 & Kısaç & 15 & 15 & 162 & 200 & 0 & 362 \\
\hline 32 & Dağçukuranı & 9 & 9 & 101 & 112 & 0 & 213 \\
\hline 33 & Elpirek & 3 & 3 & 36 & 35 & 0 & 71 \\
\hline 34 & Yakublar & 5 & 5 & 59 & 72 & 0 & 131 \\
\hline 35 & Ödülller & 2 & 2 & 45 & 40 & 0 & 85 \\
\hline 36 & Virancık & 2 & 2 & 30 & 32 & 0 & 62 \\
\hline 37 & Tirbaşı & 19 & 19 & 183 & 276 & 0 & 459 \\
\hline 38 & Viran & 35 & 39 & 527 & 546 & 0 & 1073 \\
\hline \multicolumn{2}{|c|}{ Genel Toplam } & 607 & 613 & 6433 & 7892 & 11 & 14336 \\
\hline
\end{tabular}

Şehir merkezini oluşturan mahallelerin gayri mezru arazi dağlımı büyüklük sırasına göre 626 dönümle Karalar Mahallesi, 472 dönümle İdris Mahallesi, 338 dönümle Kurtlar Mahallesi ve 238 dönümle Okçular Mahallesi gelmektedir. O halde şehir merkezine ait toplam 3.245 dönüm arazinin 1.571 dönümünde tarımsal faaliyet yapılırken ve 1.674 dönümünde de tarımsal faaliyet yapılamayıp nadasa bırakılması dikkat çekicidir. 613 haneli 
Çerkeş Kasabası genelinde ise toplam ekilmeyip nadasa bırakılan alanlar 7.892 dönümdür. Hane başına 13 dönüme yakın ekilmeyen alan düşmektedir. Ayrıca şehir merkezinde çayır için ayrılmış bir alan da bulunmamaktadır.

Çerkeş kasabasının gerek mahallelerine ait ve gerekse köylerine ait arazilerin önemli ölçüde gayri mezru olarak gözükmesi kasabanın topraklarında geniş bir bölümün zayıf bir bitki örtüsü ile kaplı olduğu izlenimini vermektedir. Kasaba halkı bu durum karşısında daha iyi verim alabilmek için arazisinden bir kısmını nadasa bırakmak zorunda kalmıştır. Çünkü bu nevi topraklarda tarımsal faaliyet yapma sulama ve bakımla olabilmektedir. Nitekim kasaba dâhilinde en fazla nadasa bırakılmış arazinin bulunduğu yerleşim yeri Karalar Mahallesidir. Nadasa bırakılmış arazilerin 25 adedi küçük işletme büyüklüğünde ve 24 adedi de orta işletme büyüklügündedir.

XIX. yüzyılın ortalarında Çerkeş Kazasına bağlı 38 adet köy yerleşim yerlerine ait arazi dağılımı Tablo 8/b'de görülmektedir. Tüm köy yerleşim yerlerindeki araziler toplamda 14.335,5 dönüme ulaşmaktadır. $\mathrm{Bu}$ arazinin ancak $6.432,5$ dönümünde zirai faaliyet yapılırken, 7.892 dönümlük kısmında zirai faaliyet yapılmayıp arazinin dinlenmesi için nadasa bırakılmıştır. Ayrıca hayvanların otlatılması için 11 dönümlük bir arazi de çayır olarak ayrılmıştır. Tabloda dikkati çeken en önemli hususlardan birisi toplamda ekili alanlardan daha fazla bir arazinin nadasa bırakılmış olmasıdır.

Köylerin toplam arazi dağılımının verildiği Tablo 8/b'de de görüldüğü gibi Çerkeş köyleri içerisinde en fazla araziye sahip olan yerleşim yeri 1.234 dönüm ile Saçak köyüdür. Bu köyün 556 dönümünde tarım yapılırken ve 676 dönümünde ise tarımsal faaliyet yapılamamıştır. Köyler içerisinde arazi büyüklüğü bakımından ikinci sırayı 1.073 dönüm ile Viran karyesi almaktadır. Bu köyün arazisinin 527 dönümünde tarım yapılmış, 546 dönümünde ise gelecek yıl daha iyi ürün alabilmek maksadıyla arazi dinlenmeye birakılmıştır.

\begin{tabular}{|c|c|c|c|c|c|c|c|}
\hline \multicolumn{7}{|c|}{ Tablo 8/c. Çiftliklerin Arazi Dağılımı (Dönüm) } \\
\hline $\begin{array}{c}\text { Sıra } \\
\text { No }\end{array}$ & Yerleşim Birimi & $\begin{array}{c}\text { Numaralı } \\
\text { Hane }\end{array}$ & Netice & $\begin{array}{c}\text { Mezru } \\
\text { Tarla }\end{array}$ & $\begin{array}{c}\text { Gayri Mezru } \\
\text { Tarla }\end{array}$ & Çayır & $\begin{array}{c}\text { Toplam } \\
\text { Arazi }\end{array}$ \\
\hline 1 & Çiftlik Basmul & 1 & 1 & 25 & 20 & 0 & 45 \\
\hline
\end{tabular}

Çayır alanı olarak ayrılmış alanların durumu Çerkeş köyleri genelinde şöyledir. Köyler içerisinde Yalakçukuranı köyünde 4 dönüm, Saçak köyünde 2 dönüm, Hacılar köyünde 1 dönüm, Çalcaviran köyünde 2 dönüm, Bayındır köyünde 2 dönüm olmak üzere toplam 11 dönümlük alan hayvanların otlaması için çayır alanı olarak ayrılmış bulunmaktadir.

Çerkeş kasabasının yerleşim yerlerinden Basmul Çiftliğinde toplam olarak 45 dönümlük arazi bulunmaktadır. Tablo 8/c'de görüldüğü gibi bu arazinin 25 dönümlük kısmında zirai faaliyetin yapıldığı ve kalan 20 dönümlük kısmının da nadasa bırakıldığı anlaşılmaktadır. Çünkü tarım arazilerinin büyük bir kısmının zayıf bir bitki örtüsü ile kaplı olduğu bilinmektedir. 


\begin{tabular}{|l|l|c|c|c|c|}
\hline \multicolumn{6}{|c|}{ Tablo 9/a. Osmanlı Ziraat İstatistikleri Açısından Çerkeş Mahallelerinin } \\
Büyüklüklerine Göre Toplam Arazi Dağılım
\end{tabular}

Osmanlı ziraat istatistiklerinde 10 dönüme kadar olan ziraat işletmeleri küçük, 10 50 dönüm arasındaki ziraat işletmeleri orta ve 50 dönümden fazla olan ziraat işletmeler ise büyük işletme olarak kabul edilmektedir. ${ }^{5}$ Bu ölçüler açısından yani XIX. yüzyıl ortalarında Çerkeş kazasındaki arazilerin Osmanlı Ziraat İstatistikleri Açısından dağılımı Tablo 9/a, Tablo 9/b ve Tablo 9/c'de görülmektedir. Söz konusu tablolar 1şığında şöyle yorum yapabiliriz: Tüm kasaba arazileri içerisinde 50 dönümden büyük araziye sahip olan altı hane halkı bulunmaktadır. Bunlar da çoğunluk olarak şehir merkezindedir. Çerkeş kazasının genelinde toplam 17.625,5 dönümlük arazinin 627 dönümü orta işletme büyüklüğünde, 78 dönümü de küçük işletme büyüklüğündedir. Kısaca toplam 43 yerleşim yerinden oluşan Çerkeş kasabasına ait arazilerin büyük çoğunluğu, arazi büyüklüğü bakımından orta büyüklükteki işletmeler tipinde arazilerdir, denilebilir.

Osmanlı ziraat istatistikleri açısından şehir merkezinde 114 hanenin arazisi orta işletme büyüklüğünde ve 57 hanenin arazisi de küçük işletme arazisi büyüklüğündedir. Çerkeş kasabasına ait mahallelerinin toplamında büyük işletme tipinde 4 tane hane halkının arazisi bulunmakta olup bunların 3'ü Karalar Mahallesi'nde ve 1'ide İdris Mahallesi'nde bulunmaktadır. Nitekim bu durum Tablo 9/a'da görülmektedir. Buna göre şehir merkezinde çiftçilik yapan hane reislerine ait ekili alanların büyük kısmının orta işletme olarak değerlendirilebilecek araziler olduğu ve büyük işletme olarak değerlendirilebilecek ekili arazilerin ise çok az olduğu görülmektedir. Kısaca şehir merkezine ait arazilerin çoğunluğu orta büyüklükte işletme tipindeki arazilerden oluşmaktadır.

\begin{tabular}{|c|l|c|c|c|c|}
\hline \multicolumn{6}{|c|}{ Tablo 9/b. Osmanlı Ziraat İstatistikleri Açısından Köylerin Büyüklüklerine Göre } \\
Toplam Arazi Dağılım
\end{tabular}

\footnotetext{
${ }^{5}$ Güran, Tevfik, “Osmanlı Tarım Ekonomisi, 1840-1910”, İÜİF, Türk İktisat ve İçtimaiyat Tarihi Araştırmaları Merkezi, Türk İktisat Tarihi Yıllığı, Yıl 1987, S. 1, İstanbul, 1988, s. 242 ; Kütükoğlu, a.g.m., s. 407
} 


\begin{tabular}{|c|c|c|c|c|c|}
\hline 10 & Aliözü & 21 & 0 & 18 & 0 \\
\hline 11 & Çalcaviran & 18 & 0 & 17 & 0 \\
\hline 12 & Okçuk & 14 & 0 & 14 & 0 \\
\hline 13 & Gelik & 6 & 0 & 6 & 0 \\
\hline 14 & Şeyh Doğan & 23 & 2 & 17 & 0 \\
\hline 15 & Kinık & 6 & 0 & 6 & 0 \\
\hline 16 & Kizillar & 8 & 0 & 8 & 0 \\
\hline 17 & Bedil & 15 & 0 & 15 & 0 \\
\hline 18 & Bayındır & 7 & 0 & 6 & 0 \\
\hline 19 & Kadıköy & 12 & 0 & 11 & 0 \\
\hline 20 & Çölmekci & 12 & 1 & 9 & 0 \\
\hline 21 & Dikenlü & 15 & 2 & 12 & 0 \\
\hline 22 & Karaköçek & 13 & 0 & 11 & 0 \\
\hline 23 & Yortan & 15 & 0 & 14 & 0 \\
\hline 24 & Kalfakolu & 8 & 3 & 6 & 0 \\
\hline 25 & Ağaköy & 16 & 1 & 14 & 0 \\
\hline 26 & Saraycık & 25 & 0 & 17 & 2 \\
\hline 27 & Akhasan & 10 & 0 & 9 & 0 \\
\hline 28 & Yumaklı & 24 & 1 & 21 & 0 \\
\hline 29 & Yoncalı & 8 & 1 & 4 & 0 \\
\hline 30 & Bozcaarmud & 6 & 0 & 6 & 0 \\
\hline 31 & Kısaç & 15 & 1 & 13 & 0 \\
\hline 32 & Dağçukuranı & 9 & 0 & 8 & 0 \\
\hline 33 & Elpirek & 3 & 0 & 3 & 0 \\
\hline 34 & Yakublar & 5 & 0 & 5 & 0 \\
\hline 35 & Ödülller & 2 & 0 & 2 & 0 \\
\hline 36 & Virancık & 2 & 0 & 2 & 0 \\
\hline 37 & Tirbaşı & 19 & 1 & 16 & 0 \\
\hline 38 & Viran & 39 & 0 & 35 & 0 \\
\hline \multicolumn{2}{|c|}{ Genel Toplam } & 613 & 21 & 512 & 2 \\
\hline
\end{tabular}

Tablo 9/b'de Osmanlı ziraat istatistikleri açısından köylerin büyüklüklerine göre toplam arazi dağılım görülmektedir. Büyük işletme tipinde araziye sahip olan iki hane bulunmakta olup her iki hane de Saraycık karyesinde bulunmaktadır. Şehir merkezinde olduğu gibi köyler genelinde de araziler orta işletme tipindedir.

\begin{tabular}{|c|c|c|c|c|c|}
\hline $\begin{array}{l}\text { Sira } \\
\text { No }\end{array}$ & Yerleşim Yeri & Netice & $\begin{array}{c}\text { Küçük } \\
\text { (10 Dönüm) }\end{array}$ & $\begin{array}{c}\text { Orta } \\
\text { (10,5-50 Dönüm) }\end{array}$ & $\begin{array}{c}\text { Büyük } \\
(50-\ldots \text { Dönüm) }\end{array}$ \\
\hline 1 & Çiftlik Basmul & 1 & 0 & 1 & 0 \\
\hline
\end{tabular}

Basmul çiftliği mezru tarla büyüklükleri açısından değerlendirildiğinde orta büyüklükte bir tarım işletmesini andırmaktadır. Nitekim bu husus Tablo 9/c'de görülmektedir. 
Ahmet Yurtseven

\begin{tabular}{|c|l|c|c|c|}
\hline \multicolumn{5}{|c|}{ Tablo 10/ a. Mahallelerde Arazilerin İcari Açıdan Durumu (Adet) } \\
\hline \multirow{2}{*}{ Sıra No } & \multicolumn{1}{|c|}{ Mahalle Adları } & Hane Adedi & Boş Bırakılan Arazi & $\begin{array}{c}\text { İcara Verilen } \\
\text { Arazi }\end{array}$ \\
\hline 1 & Karalar & 109 & 1 & 28 \\
\hline 2 & Okçular & 83 & 0 & 15 \\
\hline 3 & Kurtlar & 75 & 1 & 8 \\
\hline 4 & İdris & 102 & 1 & 23 \\
\hline \multicolumn{2}{|c|}{ Genel Toplam } & 369 & 3 & 74 \\
\hline
\end{tabular}

Arazileri İcara Verme Açısından: 1261 yılında Çerkeş Kasabasında bazı hanelerin arazilerini kendileri işletmeyip bir başkasına icar ile vermiş oldukları bilinmektedir. Bu durum "10" nolu tablolarda görülmektedir. Toplam 298 sayfadan ibaret olan Çerkeş Temettüat defterinde arazilerin kaydının yapıldı ğı kısımda; mesela Karalar Mahallesinde, sayfa 3, Hane 3'de "Ahara ücret vermiş olduğu”, sayfa 3, Hane 4'de "Ahara ücret ile vermiş olduğu", sayfa 5 Hane 9'da "Ahara ücret ile vermiş olduğu", sayfa 6 Hane 12'de "icar vermiş olduğu", sayfa 6 Hane 13'de "icar ile vermiş olduğu", sayfa 6 Hane 15'de "Ahara icar ile vermiş olduğu", sayfa 9 Hane 24'de "Ahara icar vermiş olduğu", sayfa 46 Hane 65 'de "icari"....gibi ifadelerle kiraya verme durumları kaydedilmiştir.

Arazilerini icara vermiş olanların çoğunluğunun, kasaba merkezindeki mahallelerde ikamet eden hane reisleri olduğu anlaş1lmaktadır. Tablo 10/a'da da görüldüğü gibi, Çerkeş'in kasaba merkezinde en fazla arazisini icara vermiş olan hanelerin bulunduğu yerleşim yerleri arasında ilk sırayı 28 hane ile Karalar Mahallesi, sonra 15 hane ile Okçular Mahallesi ve 8 hane ile Kurtlar Mahallesi gelmektedir. Köy yerleşim yerlerinde ise genelde araziler sahipleri olan hane reisleri tarafindan işlenmektedir. Nitekim Tablo 10/b'ye de yansıdığı kadarıyla en fazla arazinin icara verildiği köy yerleşim yeri sırası ile Bozoğlu köyü, Kadıközü köyü şeklinde devam etmektedir.

\begin{tabular}{|c|c|c|c|c|}
\hline \multicolumn{5}{|c|}{ Tablo 10/ b. Köylerde Arazilerin İcari Açıdan Durumu (Adet) } \\
\hline Sıra No & $\begin{array}{c}\text { Köylerin } \\
\text { Adları }\end{array}$ & $\begin{array}{c}\text { Hane } \\
\text { Adedi }\end{array}$ & $\begin{array}{c}\text { Boş Bırakılan } \\
\text { Arazi }\end{array}$ & $\begin{array}{c}\text { İcara Verilen } \\
\text { Arazi }\end{array}$ \\
\hline 1 & Bozoğlu & 54 & 3 & 8 \\
\hline 2 & Ahur & 21 & 2 & 0 \\
\hline 3 & Yalaközü & 15 & 1 & 0 \\
\hline 4 & Yalakçukuranı & 25 & 0 & 0 \\
\hline 5 & Saçak & 55 & 6 & 1 \\
\hline 6 & Kara Mustafa & 14 & 0 & 0 \\
\hline 7 & Kadıözü & 22 & 6 & 2 \\
\hline 8 & Eymür & 9 & 4 & 0 \\
\hline 9 & Hacılar & 22 & 1 & 1 \\
\hline 10 & Aliözü & 21 & 1 & 0 \\
\hline 11 & Çalcaviran & 18 & 5 & 0 \\
\hline 12 & Okçuk & 14 & 2 & 0 \\
\hline 13 & Gelik & 6 & 2 & 1 \\
\hline 14 & Şeyh Doğan & 23 & 6 & 0 \\
\hline 15 & Kınık & 6 & 0 & 0 \\
\hline 16 & Kızıllar & 8 & 1 & 0 \\
\hline 17 & Bedil & 15 & 1 & 0 \\
\hline
\end{tabular}




\begin{tabular}{|l|l|c|c|c|}
\hline 18 & Bayındır & 7 & 2 & 0 \\
\hline 19 & Kadıköy & 12 & 0 & 0 \\
\hline 20 & Çölmekci & 12 & 3 & 0 \\
\hline 21 & Dikenlü & 15 & 3 & 0 \\
\hline 22 & Karaköçek & 13 & 0 & 1 \\
\hline 23 & Yortan & 15 & 0 & 0 \\
\hline 24 & Kalfakolu & 8 & 0 & 0 \\
\hline 25 & Ağaköy & 16 & 2 & 0 \\
\hline 26 & Saraycık & 25 & 1 & 1 \\
\hline 27 & Akhasan & 10 & 0 & 0 \\
\hline 28 & Yumaklı & 24 & 0 & 0 \\
\hline 29 & Yoncalı & 8 & 0 & 0 \\
\hline 30 & Bozcaarmud & 6 & 0 & 0 \\
\hline 31 & Kısaç & 15 & 0 & 0 \\
\hline 32 & Dağçukuranı & 9 & 2 & 0 \\
\hline 33 & Elpirek & 3 & 0 & 0 \\
\hline 34 & Yakublar & 5 & 0 & 0 \\
\hline 35 & Ödülller & 2 & 0 & 0 \\
\hline 36 & Virancık & 2 & 0 & 0 \\
\hline 37 & Tirbaş1 & 19 & 2 & 0 \\
\hline 38 & Viran & 39 & 1 & 0 \\
\hline Genel Toplam & 613 & 57 & 14 \\
\hline & & & & \\
\hline
\end{tabular}

1261 yılında Çerkeş Kasabasının tüm köylerinde arazisini kendisi işletmeyip icar ile vermiş olan hane reisi hiç bulunmamaktadır. Köy yerleşim yerlerindeki tüm haneler kendi arazilerini bizzat kendileri ekip biçmektedir. Ancak bazı hanelerin çeşitli nedenlerle tarımsal faaliyette bulunmadıkları anlaşılmaktadır. Çalışma konumuz olan 1261 tarihli Çerkeş Temettüat Defterindeki bilgilere göre, hane reislerinden kimisi askerlik vazifesini yapmakta olduğu için, kimisi tarımsal faaliyet yapmaya yetecek güç ve kuvveti olmadığı için, kimisinin özürlü olmasından dolayı, kimisinin vefat etmiş olmasıyla geride bıraktığı arazisini işleyecek bir mirasçısının olmaması, kimisinin emlak ve arazisi olmadığı için, kimisinin de hanesini başka bir yere nakletmiş olması dolayısıyla söz konusu yerleşim yerlerinde tarımsal faaliyette bulunamadı̆̆

İcar İle Arazi İșleyenler: Çerkeş Kasabasının yerleşim yerlerinde yeterli araziye sahip olmadığından veya başka bir sebepten dolayı başkasının arazisini kiralayarak işleten hanelerin sayısı 45'i bulmaktadır. Kasaba genelinde bazı haneler başkasının toprağını kiralayarak işletmektedir. Kiralanan arazilerin en fazla bulunduğu yerleşim yerleri sirasıyla Karalar Mahallesi, İdris Mahallesi, Okçular Mahallesi, Kurtlar Mahallesi ve Bozoğlu karyesi, Kadiözü karyesi ve bu yerleşim yerlerini Saçak karyesi, Haclar karyesi, Gelik karyesi ve Saraycık karyesi takip etmektedir. Nitekim bu durum rakamlarla Tablo 10 /a'da mahalleler ve Tablo $10 / \mathrm{b}$ 'de ise köyler genelinde görülmektedir.

İnceleme konumuz olan 1261 tarihli Çerkeş Temettüat defterine göre, Çerkeş kasabası genelinde sadece bir adet olduğu anlaşılan Basmul çiftliğinde ise icara verilmiş arazi bulunmamaktadir.

Arazisini Boș Bırakanlar: Çerkeş Kasabası genelinde bazı aileler çeșitli sebeplerle arazilerinde zirai faaliyet yapamayıp boș bırakmıșlardır. Arazilerini boṣ bırakarak zirai 
faaliyet yapamayan toplam 60 hane reisinden 4 hane reisi șehir merkezine ait mahallelerde bulunmaktadır. Çerkeş Temettüat defterindeki verilere göre, kimi hane reislerinin arazilerini ekip biçmeyip boș bırakmak mecburiyetinde kalıs sebepleri arasında; zirai faaliyet yapacak güç ve kudretlerinin olmaması, askerlik hizmetini yapmakta olmaları, kendisinin kötürüm olması ve erkek evladının olmaması, özürlü ve sakatlığının olması gibi halleri sıralayabiliriz.

\section{Diğer Mal Varlıkları}

\begin{tabular}{|c|c|c|c|c|c|c|c|}
\hline \multicolumn{8}{|c|}{ Tablo 11/a. Mahallelerin Diğer Mal Varıklarının Dağılımı } \\
\hline $\begin{array}{l}\text { Sira } \\
\text { No }\end{array}$ & $\begin{array}{c}\text { Mahalle } \\
\text { Adı }\end{array}$ & Hane Adedi & $\begin{array}{c}\text { Dükkân } \\
\text { (Bab) }\end{array}$ & Asiyab (Bab) & $\begin{array}{l}\text { Kahve } \\
(\mathrm{Bab})\end{array}$ & $\begin{array}{l}\text { Kahve } \\
\text { (Nisfi) }\end{array}$ & $\begin{array}{l}\text { Toplam } \\
\text { Emlak }\end{array}$ \\
\hline 1 & Karalar & 109 & 3 & 0 & 2 & 2 & 7 \\
\hline 2 & Okçular & 83 & 8 & 0 & 0 & 0 & 8 \\
\hline 3 & Kurtlar & 75 & 1 & 0 & 0 & 0 & 1 \\
\hline 4 & İdris & 102 & 4 & 1 & 1 & 0 & 6 \\
\hline \multicolumn{2}{|c|}{ Genel Toplam } & 369 & 16 & 1 & 3 & 2 & 22 \\
\hline
\end{tabular}

İncelemeye çalıştı̆̆ımız Çerkeş Temettüat Defteri’ne göre 1261 yılında kasaba halkının arazi ve hayvanlarından başka mal varlıkları da bulunmaktadır. Mesela dükkân, asiyab (su değirmeni), kahve gibi. Bu mal varlıklarını diğer mal varlıkları adı altında toplayabiliriz.

\begin{tabular}{|c|l|c|c|c|c|c|c|}
\hline \multicolumn{7}{|c|}{ Tablo 11/b. Köylerin Diğer Mal Varlıklarının Dă̆ılımı } \\
\hline $\begin{array}{c}\text { Sıra } \\
\text { No }\end{array}$ & Köy Adları & $\begin{array}{c}\text { Hane } \\
\text { Adedi }\end{array}$ & $\begin{array}{c}\text { Dükkan } \\
(\text { Bab })\end{array}$ & $\begin{array}{c}\text { Asiyab } \\
(\text { Bab })\end{array}$ & $\begin{array}{c}\text { Kahve } \\
(\text { Bab })\end{array}$ & $\begin{array}{c}\text { Kahve } \\
(\text { Nisfi })\end{array}$ & $\begin{array}{c}\text { Toplam } \\
\text { Emlak }\end{array}$ \\
\hline 1 & Bozoğlu & 54 & 0 & 0 & 0 & 0 & 0 \\
\hline 2 & Ahur & 21 & 0 & 0 & 0 & 0 & 0 \\
\hline 3 & Yalaközü & 15 & 0 & 3 & 0 & 0 & 3 \\
\hline 4 & Yalakçukuranı & 25 & 0 & 0 & 0 & 0 & 0 \\
\hline 5 & Saçak & 55 & 0 & 0 & 0 & 0 & 0 \\
\hline 6 & Kara Mustafa & 14 & 0 & 2 & 0 & 0 & 2 \\
\hline 7 & Kadı̈̈zü & 22 & 0 & 0 & 0 & 0 & 0 \\
\hline 8 & Eymür & 9 & 0 & 0 & 0 & 0 & 0 \\
\hline 9 & Hacılar & 22 & 0 & 0 & 0 & 0 & 0 \\
\hline 10 & Aliözü & 21 & 0 & 0 & 0 & 0 & 0 \\
\hline 11 & Çalcaviran & 18 & 0 & 0 & 0 & 0 & 0 \\
\hline 12 & Okçuk & 14 & 0 & 0 & 0 & 0 & 0 \\
\hline 13 & Gelik & 6 & 0 & 0 & 0 & 0 & 0 \\
\hline 14 & Şeyh Doğan & 23 & 0 & 0 & 0 & 0 & 0 \\
\hline 15 & Kınık & 6 & 0 & 0 & 0 & 0 & 0 \\
\hline 16 & Kızıllar & 8 & 0 & 0 & 0 & 0 & 0 \\
\hline 17 & Bedil & 15 & 0 & 0 & 0 & 0 & 0 \\
\hline 18 & Bayındır & 7 & 0 & 0 & 0 & 0 & 0 \\
\hline 19 & Kadı̈öy & 12 & 0 & 0 & 0 & 0 & 0 \\
\hline 20 & Çölmekci & 12 & 0 & 0 & 0 & 0 & 0 \\
\hline
\end{tabular}




\begin{tabular}{|c|l|c|c|c|c|c|c|}
21 & Dikenlü & 15 & 0 & 0 & 0 & 0 & 0 \\
\hline 22 & Karaköçek & 13 & 0 & 0 & 0 & 0 & 0 \\
\hline 23 & Yortan & 15 & 0 & 0 & 0 & 0 & 0 \\
\hline 24 & Kalfakolu & 8 & 0 & 0 & 0 & 0 & 0 \\
\hline 25 & Ağaköy & 16 & 0 & 0 & 0 & 0 & 0 \\
\hline 26 & Saraycık & 25 & 1 & 1 & 0 & 0 & 2 \\
\hline 27 & Akhasan & 10 & 0 & 0 & 0 & 0 & 0 \\
\hline 28 & Yumaklı & 24 & 0 & 0 & 0 & 0 & 0 \\
\hline 29 & Yoncalı & 8 & 0 & 0 & 0 & 0 & 0 \\
\hline 30 & Bozcaarmud & 6 & 0 & 0 & 0 & 0 & 0 \\
\hline 31 & Kisaç & 15 & 0 & 0 & 0 & 0 & 0 \\
\hline 32 & Dağçukuranı & 9 & 0 & 0 & 0 & 0 & 0 \\
\hline 33 & Elpirek & 3 & 0 & 0 & 0 & 0 & 0 \\
\hline 34 & Yakublar & 5 & 0 & 0 & 0 & 0 & 0 \\
\hline 35 & Ödülller & 2 & 0 & 0 & 0 & 0 & 0 \\
\hline 36 & Virancık & 2 & 0 & 0 & 0 & 0 & 0 \\
\hline 37 & Tirbaşı & 19 & 0 & 0 & 0 & 0 & 0 \\
\hline 38 & Viran & 39 & 0 & 0 & 0 & 0 & 0 \\
\hline \multicolumn{2}{|c|}{ Genel Toplam } & 613 & 1 & 6 & 0 & 0 & 7 \\
\hline
\end{tabular}

Çerkeş kasabasında 1261 tarihinde genel olarak diğer mal varlıklarının dağılımı şehir merkezi (Tablo 11/a) ve köy yerleşim yerleri (Tablo 11/b) olarak iki ayrı tabloda gösterdik. Buna göre kasaba genelinde 17 adet dükkân, 7 adet değirmen, 3 adet kahve ve 2 adet de nısf kahve bulunmaktadır.

Diğer mal varlıkları dağılımı açısından mahallelere baktığımızda 16 adet dükkân, 1 adet değirmen, 3 adet kahve ve 2 adet de nısf kahve bulunmaktadır (Tablo 11/a). Buna göre 17 dükkânın 16'sı kasaba merkezinde bulunmaktadır. En fazla dükkân 8 adet ile Okçular Mahallesi'nde ve en az dükkân da ladet ile Kurtlar Mahallesi'nde müşterilerine hizmet vermekteydi. Ayrıca kasaba merkezinde bir adet de değirmen bulunmaktadır. İdris Mahallesinde bulunan bu şehir merkezinin tek değirmeni tüm kasaba halkına yönelik hizmet vermekteydi.

Köy halkının arazi ve hayvanlarından başka temettüat defterinde kayıtlı bulunan mal varlıkları toplam yedi adet olarak görülmektedir(Tablo 11/b). Bunların biri dükkân ve diğerleri de su değirmenidir. Dükkân Saraycık karyesinde, su değirmenlerinin ise 3 adedi Yalaközü karyesinde, 2 adedi Kara Mustafa karyesinde ve 1 adedi de Saraycık karyesinde bulunmaktadır.

\section{Toplam Gelir Durumu}

Vergi: Devletin, hazinesine gelir sağlamak için kanunlara uygun olarak doğrudan doğruya veya mal ve hizmetlerin fiyatlarına ekleyerek dolaylı olarak kişi veya topluluklardan almak zorunda olduğu paradır. Devlet, hazinesinde biriken bu paralarla yapacağı kamu hizmetlerinin ve çeşitli harcamalarının finansmanını karşılamaya çalışmaktadır. Hemen hemen bütün devletlerin vergiye yaklaşımı bu şekildedir. 


\begin{tabular}{|c|l|c|c|c|c|c|}
\hline \multicolumn{7}{|c|}{ Tablo 12/a. Mahallelerde Toplam Gelir, Toplam Vergi ve Muaf Tutulanlar } \\
\hline $\begin{array}{c}\text { S1ra } \\
\text { No }\end{array}$ & $\begin{array}{c}\text { Mahalle } \\
\text { Adlar1 }\end{array}$ & $\begin{array}{c}\text { Hane } \\
\text { Adedi }\end{array}$ & Nüfus & $\begin{array}{c}\text { Toplam Temettuat } \\
\text { (Kuruş) }\end{array}$ & $\begin{array}{c}\text { Toplam Vergi } \\
\text { (Kuruş) }\end{array}$ & $\begin{array}{c}\text { Vergiden Muaf } \\
\text { Tutulanlar }\end{array}$ \\
\hline 1 & Karalar & 109 & 545 & 34471 & 13658 & 2 \\
\hline 2 & Okcular & 83 & 415 & 23253 & 9808 & 0 \\
\hline 3 & Kurtlar & 75 & 375 & 25045 & 10719 & 1 \\
\hline 4 & İdris & 102 & 510 & 36300 & 14480 & 1 \\
\hline \multicolumn{2}{|c|}{ Genel Toplam } & 369 & 1845 & 119069 & 48665 & 4 \\
\hline
\end{tabular}

Osmanlı Devleti'nde mükelleflerden alınan vergiler iki türlüdür. Bunlar şer'i vergiler (Tekâlif-i Şer'iyye) ve örfi vergiler (Tekâlif-i Örf'iyye) başlıkları altında toplanır. Şer'i vergiler (şeriatın ön gördüğü vergiler)'in başında zekât, öşür, haraç ve cizye gelmektedir. Zekât ve öşür Müslüman mükelleflerden alınırken, Gayr-i Müslim mükelleflerden ise haraç ve cizye adlı vergiler alınmaktaydı. Örfi vergiler, ortaya çıkan mali sıkıntılar sebebiyle kanunnamelerle zaman ve şartlara göre miktarı tespit edilerek mükelleflerden alınan vergilerdir.

Tablo 12/b. Köylerde Toplam Gelir, Toplam Vergi ve Muaf Tutulanlar

\begin{tabular}{|c|l|c|c|c|c|c|}
\hline $\begin{array}{c}\text { Sıra } \\
\text { No }\end{array}$ & Köy Adları & $\begin{array}{c}\text { Hane } \\
\text { Adedi }\end{array}$ & Nüfus & $\begin{array}{c}\text { Toplam } \\
\text { Temettuat } \\
\text { (Kuruş) }\end{array}$ & $\begin{array}{c}\text { Toplam } \\
\text { Vergi } \\
\text { (Kuruş) }\end{array}$ & $\begin{array}{c}\text { Vergiden } \\
\text { Muaf } \\
\text { Tutulanlar }\end{array}$ \\
\hline 1 & Bozoğlu & 54 & 270 & 24460 & 10300 & 3 \\
\hline 2 & Ahur & 21 & 105 & 11245 & 4690 & 2 \\
\hline 3 & Yalaközü & 15 & 75 & 6535 & 2614 & 1 \\
\hline 4 & Yalakçukuranı & 25 & 125 & 13508 & 5426,5 & 0 \\
\hline 5 & Saçak & 55 & 275 & 31200 & 12798 & 6 \\
\hline 6 & Kara Mustafa & 14 & 70 & 7026 & 2811 & 0 \\
\hline 7 & Kadı̈̈zü & 22 & 110 & 14329 & 6101 & 6 \\
\hline 8 & Eymür & 9 & 45 & 1883 & 753 & 7 \\
\hline 9 & Hacılar & 22 & 110 & 8223 & 3287 & 1 \\
\hline 10 & Aliözü & 21 & 105 & 9457 & 3813 & 1 \\
\hline 11 & Çalcaviran & 18 & 90 & 10895 & 4358 & 5 \\
\hline 12 & Okçuk & 14 & 70 & 8030 & 3260 & 3 \\
\hline 13 & Gelik & 6 & 30 & 4637 & 1985 & 2 \\
\hline 14 & Şeyh Doğan & 23 & 115 & 12985 & 5394 & 8 \\
\hline 15 & Kınık & 6 & 30 & 32722 & 1301 & 0 \\
\hline 16 & Kızıllar & 8 & 40 & 5105 & 2010 & 1 \\
\hline 17 & Bedil & 15 & 75 & 7310 & 3100 & 1 \\
\hline 18 & Bayındır & 7 & 35 & 5045 & 2188 & 1 \\
\hline 19 & Kadıöy & 12 & 60 & 6770 & 2903 & 0 \\
\hline 20 & Çölmekci & 12 & 60 & 4382 & 1813 & 3 \\
\hline 21 & Dikenlü & 15 & 75 & 9232 & 3893 & 4 \\
\hline 22 & Karaköçek & 13 & 65 & 5837 & 2335 & 0 \\
\hline 23 & Yortan & 15 & 75 & 9475 & 3953 & 0 \\
\hline 24 & Kalfakolu & 8 & 40 & 4792 & 2067 & 0 \\
\hline 25 & Ağaköy & 16 & 80 & 8357 & 3337 & 2 \\
\hline 26 & Saraycık & 25 & 125 & 10502 & 4281 & 1 \\
\hline
\end{tabular}




\begin{tabular}{|c|l|c|c|c|c|c|}
27 & Akhasan & 10 & 50 & 6460 & 3692 & 0 \\
\hline 28 & Yumaklı & 24 & 120 & 11015 & 4402 & 3 \\
\hline 29 & Yoncalı & 8 & 40 & 3315 & 1324 & 0 \\
\hline 30 & Bozcaarmud & 6 & 30 & 2160,5 & 864 & 0 \\
\hline 31 & Kisaç & 15 & 75 & 7525,5 & 2858 & 0 \\
\hline 32 & Dağçukuranı & 9 & 45 & 4662 & 1865 & 0 \\
\hline 33 & Elpirek & 3 & 15 & 1560,5 & 624 & 0 \\
\hline 34 & Yakublar & 5 & 25 & 2701 & 1080 & 0 \\
\hline 35 & Ödülller & 2 & 10 & 2010 & 804 & 0 \\
\hline 36 & Virancık & 2 & 10 & 1841 & 736 & 0 \\
\hline 37 & Tirbaş1 & 19 & 95 & 13833,5 & 5544 & 2 \\
\hline 38 & Viran & 39 & 195 & 19133 & 7652 & 1 \\
\hline \multicolumn{2}{|c|}{ Genel Toplam } & 613 & 3065 & 350159 & 132217 & 64 \\
\hline
\end{tabular}

Osmanlı Devleti'nin örfi vergi koyması bir zaruretin sonucuydu. Mesela Osmanlı Devleti'nde ilk örfi vergin konulması hakkında şöyle denilmektedir: "Harpler, sıkıntılı günler yaşayan hazineyi daha da zor durumda bırakıyordu. İşte bunun için devlet II. Bayezid'in son senelerine tesadüf eden günlerde ilk olarak "imadiyye- i seferiye" adı ile ilk örfi vergisini koymuş oluyordu.". 6 Daha sonra ihtiyaca binaen başka örfi vergiler konulmuştur. Birbirini takip eden savaşlar neticesinde de örfi vergiler devamlılık arz etmiştir. Vergilerdeki çeşitlilik, halk üzerinde olumsuz etkiler meydana getirmiş ve istismarcıların bu mevcut durumdan faydalanmak istemeleri ise halkı canından bezdirmiştir.

Osmanlı Devleti'nde XIX. yüzyılın ortalarında temettüat sayımlarının yapılmasının temel gayesi vergi sisteminin alt yapısının oluşturulmasıdır. Temettüat defterlerinde haneler yazılırken hane reisinin yıllık vergisinin ne kadar olduğu "verguy-u seneviyyesi " ibaresi altında belirtilmiş, ayrıca zirai ürünlerden alınan öşür ve küçükbaş hayvanlardan alınan ağnam vergisi de kayıt edilmiştir.

XIX. yüzyılın ortalarında Osmanlı Devleti mali sıkıntılarını giderebilmek için yeni vergi düzenlemesine gitmiştir. Bunun bir yansıması olarak düzenlenen temettüat defterlerinden biri olan incelemeye çalıştığımız Çerkeş Temettüat defterine göre XIX. yüzyılın ortalarında Çerkeş Kasabasında toplam gelir ve toplam vergi dağılımı 12 nolu tablolarda görülmektedir. Buna göre söz konusu tarihte kasaba genelinde toplanan toplam gelir 469.953 kuruş olarak gerçekleşmiş ve bu meblağ üzerinden toplam olarak 181.171 kuruş vergi $(\% 38,55)$ tahakkuk ettirilmiştir.

En fazla geliri olan yerleşim yerleri sırasıyla; 36.300 kuruş $(\% 7,72)$ ile İdris Mahallesi, 34.471 (\% 7,33) kuruş ile Karalar Mahallesi, 32.722 kuruş $(\%$ 6,96) ile Kınık karyesi, 31.200 kuruş (\% 6,63) ile Saçak karyesi ve 25.045 kuruş (\% 5,33) ile Kurtlar Mahallesi gelmektedir. En az geliri olan yerleşim yerleri ise 725 kuruş $(\% 0,15)$ ile Çiftlik Basmul, 1841 kuruş $(\%$ 0,39) ile Virancık karyesi ve 1.883 kuruş $(\% 0,4)$ ile Eymür karyesi gelmektedir.

En fazla vergi veren yerleşim yerleri sırasıyla 14.480 kuruş (\% 8) ile İdris Mahallesi, 13.658 kuruş (\% 7,53) ile Karalar Mahallesi, 12.798 kuruş $(\% 7,1)$ ile Saçak Karyesi, 10.719 kuruş (\% 5,9) ile Kurtlar Mahallesi ve 10.300 kuruş (\% 5,68) ile Bozoğlu Karyesi

\footnotetext{
${ }^{6}$ KAZICI, Ziya, Osmanlılarda Vergi Sistemi, Şamil Yayınevi, İstanbul, 1977, s.155.
} 
gelmektedir. En az vergi veren yerleşim yerleri ise sırasıyla 289 kuruş $(\% 0,15)$ ile Çiftlik Basmul ve 624 kuruş (\% 0,34) ile Elpirek Karyesi gelmektedir.

\begin{tabular}{|c|c|c|c|c|c|}
\hline \multicolumn{6}{|c|}{ Tablo 12/c. Çiftlikte Toplam Gelir, Toplam Vergi ve Muaf Tutulanlar } \\
\hline Yerleşim Yeri & $\begin{array}{c}\text { Hane } \\
\text { Adedi }\end{array}$ & Nüfus & $\begin{array}{c}\text { Toplam Temettuat } \\
\text { (Kuruş) }\end{array}$ & $\begin{array}{c}\text { Toplam Vergi } \\
\text { (Kuruş) }\end{array}$ & $\begin{array}{c}\text { Vergiden Muaf } \\
\text { Tutulanlar }\end{array}$ \\
\hline Çiftlik Basmul & 1 & 5 & 725 & 289 & 0 \\
\hline
\end{tabular}

Çiftlik, köy yerleşim yerinin altında ve tek haneli arazi parçasıdır. Çerkeş kasabası yerleşim yerleri arasında mahalleler, köyler yanında bir de "Çiftlik Basmul" adı altında bir adet çiftlik bulunmaktadır. Söz konusu çiftlikte toplam olarak 289 Kuruş vergi tahakkuk ettirilmiştir. Nitekim bu durum Tablo 12/c'de görülmektedir.

Vergiden Muaf Tutulanlar: XIX. yüzyılın ortalarında 1260-1261 yılında çeşitli sebeplerden dolayı vergi verecek durumda olmadıkları için vergiden muaf tutulanlar bulunmaktadır. Bu durum da 12 nolu tablolara yansitılmıştır. ML.VRD. TMT. d. kodlu ve 00666 nolu inceleme konumuz olan Çerkeş Temettüat defterindeki verilere göre bu gurubun vergiden muaf tutulmasını sağlayan nedenleri kısaca şöyle sıralayabiliriz:

- Zirai faaliyet yapmaya güç ve kuvveti olmayanlar,

- Kendisi kötürüm ve erkek evladı olmayan,

- Zirai faaliyet yapmaya güç ve kuvveti olmayıp başkasının yardımıyla geçinmekte olanlar,

- Askerlik hizmetini yapmakta olanlar,

- Emlak ve arazisi olmayanlar,

- Başka bir yere hanesini naklederek gitmiş olanlar,

- Kötürüm ve dilsiz olduğundan,

- Hane reisi vefat etmiş, geride erkek evladı kalmamış olanlar

Tanzimat Fermanı'ndan sonra Osmanlı Devleti mali sıkıntılarını giderebilmek için idari yapıda değişiklikler ve yenilikler yapılmasını gerekli görmüş ve bu yönde yaptığı çalışmalarla vergi mükelleflerinin tespitine, vergi adaletinin sağlanmasına ve devletin gelirgider dengesini kurmaya çalışmıştır.

\section{SONUÇ VE ÖNERILER}

Çerkeş, Osmanlı Devleti döneminde sancak merkezi, Cumhuriyet döneminde ise vilayet merkezi olan Çankırı'nın 11 ilçe merkezinden birisidir.

Çerkeş ilçesi dün olduğu gibi bugün de önemli yol güzergâhında bulunmaktadır. 1261/1845 tarihli Çerkeş temettüat defterine göre XIX. yüzyılın ortalarında ilçenin ekonomisi tarım ve hayvancılığa dayanmaktadır. Gerek kasaba merkezi ve gerekse köy yerleşim yerlerinde toplam olarak 983'e ulaşan hane reislerinin ekonomiye katkıları farklı oranlarda olmuştur. Hatta kimi hane reislerinin çeşitli sebeplerle ekonomiye katkıları olmamıştır. 
Hane reislerine ait mal varlıkları, yetiştirilen hayvanlar, tarım alanları ve diğer mal varlıkları olarak sınıflandırılabilmektedir. Tarım alanları zayıf bir bitki örtüsü ile kaplı bulunduğundan tarım topraklarının bir kısmı nadasa bırakılıyordu. Daha ziyade tarım ürünleri yetiştiriyorlardı. Toplam olarak 17.625,5 dönümlük arazinin 8.029,5 dönümü (\% 45,5) mezru ve 9.586 dönümü gayrimezrudur. 114 hanenin arazisi orta işletme tipinde, 57' si (\% 50) küçük işletme, 6’sı (\% 5,26)ise büyük işletme tipindedir. Büyük işletmelerin 2' si (\% $1,75)$ Saçak köyünde bulunuyor.

Osmanlı insanının ekonomik hayatında zirai faaliyet ve hayvancılık önemli yer tutmaktadır. Genelde tarım, ailelerin kendi ihtiyaçları için; et, süt ve süt ürünleri ihtiyacı için zirai faaliyet yaparken veya çevrenin şartlarına göre büyük ve küçükbaş hayvancılık yapılıyordu. Bu mal varlıklarından başka 17 dükkân, 7 değirmen, 3 kahve, 2 nısf kahve bulunmaktadır. Bunlardan 16 dükkân, 1 değirmen, 3 kahve ve 2 nısf kahve şehir merkezindedir.

38 adet köy ve bir adet çiftlikten oluşan Çerkeş Kasabasının tüm yerleşim yerlerindeki büyükbaş hayvancılık durumu (baş olarak); sağman inek(724), boz sağman inek(114), boz inek(248) döllü merkep (146), döllü kısrak (113), kısrak (2), boz sağman camış (1), sağman camış (90), karasığır camış (0), karasığır öküzü (718) camış öküzü (63 ) olmak üzere toplam büyükbaş hayvan adedi 2219'a ulaşmaktadır.

17.625,5 dönümlük Çerkeş arazisinin çoğunluğu orta büyüklükte işletme tipinde arazidir. Arazilerini icara vermiş olanların 42' si de şehir merkezindeki mahallelerde yaşayan hane sahipleridir. Başkasının arazisini icar ile tutarak zirai faaliyet yapanlar toplam 45 hanedir. Bunun 31'i şehir merkezinde yaşamaktadır. Çeşitli nedenlerle 60 hane reisi arazisini boş bırakmıştır. Bunlardan 4'ü şehir merkezindedir. Zirai faaliyet yapmaya güç ve kudretlerinin olmaması, erkek evlatlarının olmaması, askerlik, özür ve sakatlık gibi nedenlerle arazilerini boş bırakmışlardır.

Osmanlı Devleti'nde uygulanan vergi sistemi şer'i ve örfi vergi diye ikiye ayrılmaktadır. Şer’i vergiler esas olarak Müslümanların vermek zorunda oldukları zekât ve öşür, Gayr-i Müslimlerin vermek zorunda oldukları vergiler ise cizye ve haraçtır. Örfi vergiler, ortaya çıkan mali sıkıntılar sebebiyle kanunlarla zaman ve şartlara göre konulmaktaydı. Zamanla Osmanlı Devleti'nin güç kaybetmeye başlamasıyla ortaya çıkan ayan ve mültezimler vergi toplamaya başlamışlar ve halkı canından bezdirmişlerdi.

XIX. yüzyıl ortalarında mali sıkıntıyı giderebilmek için yeni vergi düzenlemesine gidilmiştir. Bunun altyapısı olarak da halkın mal, emlak ve arazisinin tespit edilmesine yönelik olan temettüat sayımları yapılmış ve temettüat defterleri oluşturulmuştur. Temettüat sayımları 1840 ve 1845 yıllarında yapılmıştır. Bu çalışma da 1260-1261 (1845) yılında yapılan temettüat sayımlarından olup Çerkeş Kasabasına aittir. Söz konusu Çerkeş temettüat sayımı sonucunda toplam 469.953 kuruş gelir ve bunun üzerinden 181.171 kuruş $(\% 38,55)$ vergi tahakkuk ettirilmiştir. En fazla geliri olan yerleşim yerleri toplam 36.300 kuruş (\% 7,72) ile İdris Mahallesi, 32.722 kuruş $(\%$ 6,96) ile Kınık köyüdür. En az geliri olan yerler 725 kuruş $(\%$ 0,15) ile Çiftlik Basmul ve 1.841 kuruş (\% 0,39)ile Virancık köyüdür. En fazla vergi veren yerler ise 114.480 kuruş (\% 0,8) ile İdris Mahallesi, 31.200 kuruş $(\% 7,1)$ ile Saçak köyü ve en az vergi veren yerler de 289 kuruş $(\%$ 0,15) ile Çiftlik Basmul ve 624 kuruş $(\% 0,34)$ ile Elpirek köyüdür. 
Tazimat döneminde örfi vergiler, 1840 yılında "ancemaatın vergi" adında birleştirilmiştir. Daha önce sadece tarım kesiminden alınan vergilere esnaf gurubu da dâhil edilmiştir. Toplumun tüm kesimleri ödeme gücüne göre vergiye tabi tutulmuştur. Mültezimler vasıtasıyla vergi toplamaya son verilmiştir. Mahallin ileri gelenlerinden oluşan "Muhassillık Meclisi" 1840 yılında uygulamaya konuldu. Sikıntılar yüzünden 1842 yılında kaldırıldı ve "Müşirlik Nizamı” kuruldu.

Bilgiler sınırlı ve karmaşık olsa da, şehrin genel yapısı ile ilgili bir sonuç çıarabiliriz. O dönemde Osmanlının diğer kazalarında olduğu gibi temel geçim kaynă̆ tarım ve hayvancılıktır. Tarım dışı sanayi ve ticaretin ise gelişmediği anlaşılmaktadır.

Emlak olarak zirai alanların dışında çok az varlık bulunmaktadır. Hatta yok denecek kadar azdır. Çerkeş Temettuat defterindeki kayıtlara göre kasaba genelinde 17 adet dükkân, 7 adet değirmen, 3 adet kahve, 2 adet de nisf kahve bulunmaktadır.

Çerkeş Kasabasının ekonomik yapısı ziraat ve hayvancılı̆ga dayanmaktadır. Halkın tamamına yakın kısmı çiftçilikle geçimini sağlamaktadır. Aslında sanayi öncesi toplumların en belirgin özelliği tarım ve hayvancılıktır. Çerkeş kazasında hayvan yetiştiriciliği zirai faaliyetin yanında hanelerin hayvansal ürünleri ihtiyacını karşılamaya yönelik olarak yapıldığı izlenimi vermektedir.

\section{KAYNAKÇA}

\section{A- Arşiv Vesikaları}

I- Başbakanlık Osmanlı Arşivi Vesikaları:

BOA., ML. VRD. TMT. d./ 00666. (Temettuat Defteri)

\section{B- Kitaplar Ve Makaleler}

Başbakanlık Osmanlı Arşivi Daire Başkanlı̆̆ı, Osmanlı İdaresinde Kıbrıs (NüfusuArazi Dağılımı Ve Türk Vakıfları), Başbakanlık Devlet Arşivleri Genel Müdürlüğü Osmanlı Arşivi Daire Başkanlığı Yayınları, Ankara, 2000.

Güran, Tevfik, “Osmanlı Tarım Ekonomisi, 1840-1910”, IÜİF, Türk İktisat Ve İçtimaiyat Tarihi Araştırmaları Merkezi, Türk İktisat Tarihi Y1llığı, Y1l 1987, S.1, İstanbul, 1988, Ss.225-303.

Kazıc1, Ziya, Osmanlılarda İhtisap Müessesesi (Ekonomik, Dini Ve Sosyal Hayat), Kültür Basın Ve Yayın Birliği Yayınları, İstanbul, 1987.

Kazıc1, Ziya, Osmanlılarda Vergi Sistemi, Şamil Yayınevi, İstanbul, 1977.

Kütükoğlu, Mübahat S., "Osmanlı Sosyal Ve İktisadi Tarihi Kaynaklarından Temettü Defterleri”, Belleten, Türk Tarih Kurumu Yayınları, Ankara, 1995, Ss 395-412.

Parlatır, İsmail, Osmanlı Türkçesi Sözlüğü, Yargı Yayınları, Ankara, 2006. 


\section{EK BELGELER VE TABLOLAR}

Belge 1: 1261 Tarihli Çerkeș Temettüat Defterinin 6. ve 7. sayfaları

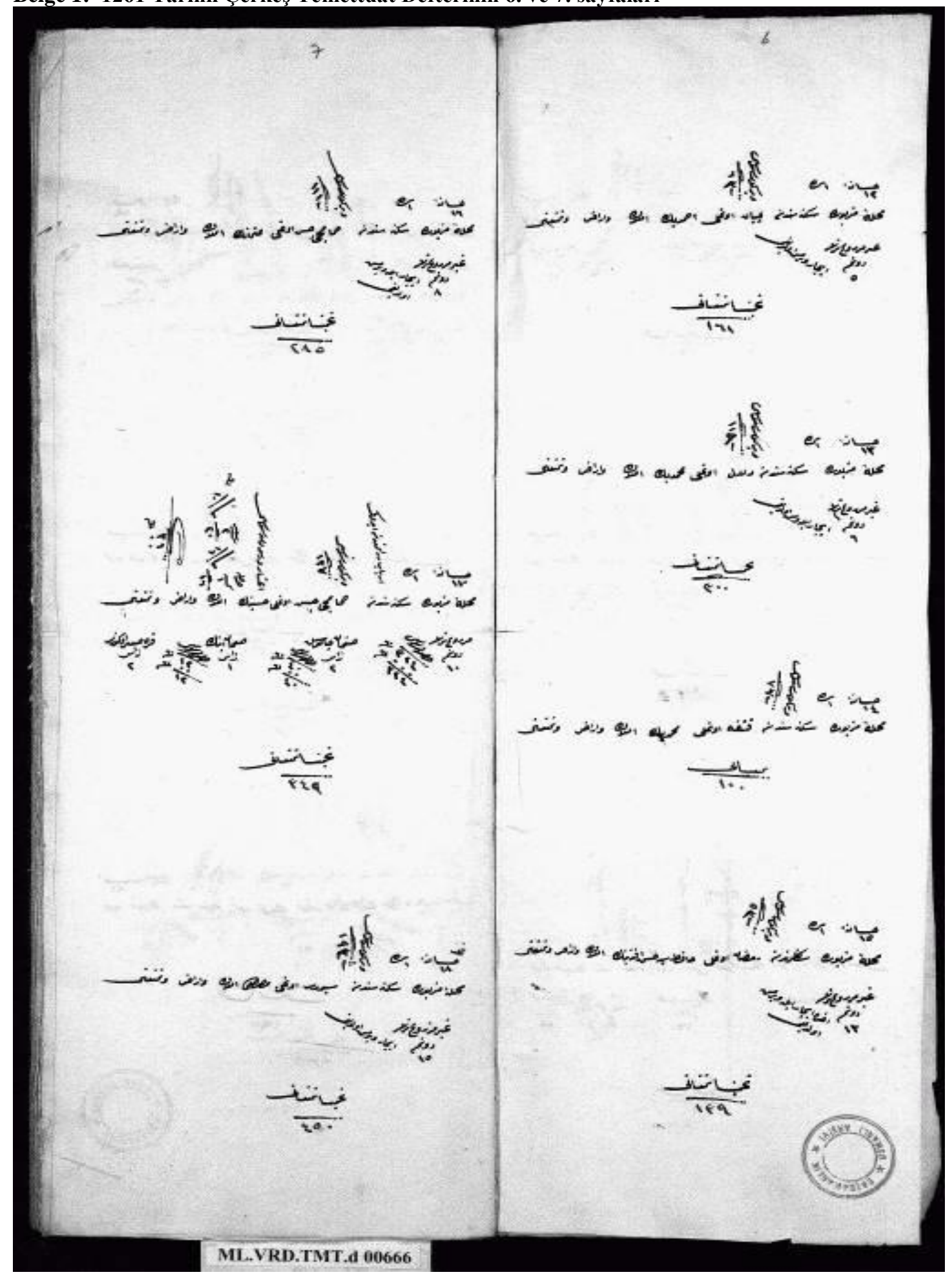


Belge 2: 1261 Tarihli Çerkeş Temettüat Defterinin 46. ve 47. sayfaları

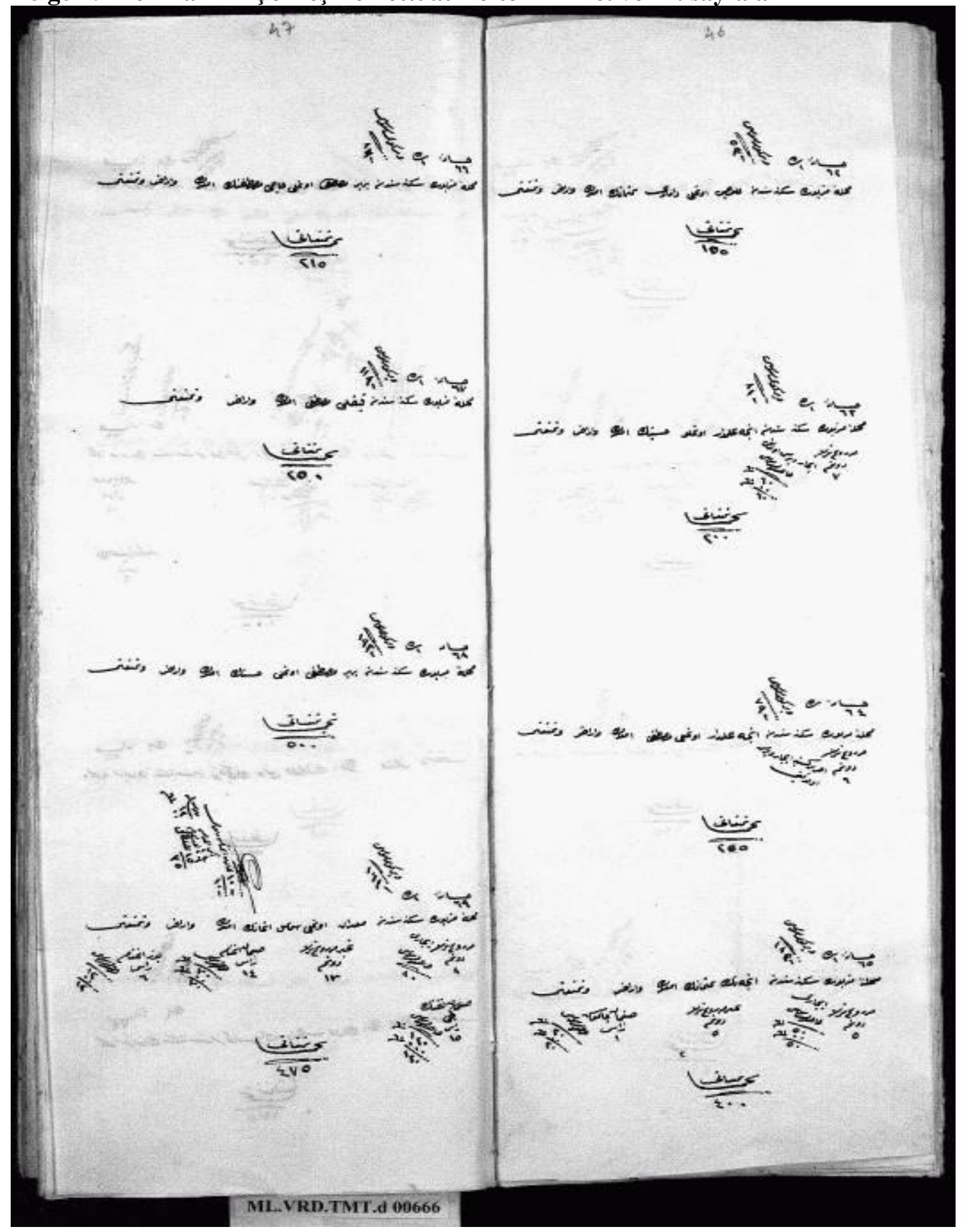

